This PDF is a selection from a published volume from the National Bureau of Economic Research

Volume Title: Social Security Programs and Retirement around the World: Micro-Estimation

Volume Author/Editor: Jonathan Gruber and David A. Wise, editors

Volume Publisher: University of Chicago Press

Volume ISBN: 0-226-31018-3

Volume URL: http://www.nber.org/books/grub04-1

Publication Date: January 2004

Title: Pension Incentives and the Pattern of Retirement in the United Kingdom

Author: Richard Blundell, Costas Meghir, Sarah Smith

URL: http://www.nber.org/chapters/c10709 


\title{
Pension Incentives and the Pattern of Retirement in the United Kingdom
}

\author{
Richard Blundell, Costas Meghir, and Sarah Smith
}

\subsection{Introduction}

Like many other Organization for Economic Cooperation and Development (OECD) countries, the United Kingdom has been experiencing a trend towards earlier labor market exits among older, particularly male, workers. The proportion of men aged sixty to sixty-four in employment halved from 1968, when 80 percent were employed, to only a little over 40 percent in 1996. The fall in the proportion of older men who were in full-time employment was even greater than the fall in the proportion in any form of employment, with a relative shift within the employed to self-employment and part-time employment (see figure 11.1). Female employment has not experienced the same downward trend - but this contrasts with rising participation among most other age groups across the same period.

This paper looks at the extent to which these trends might be explained by the financial incentives in the pension system that people faced when making their retirement decisions. In doing so, we focus not only on the

Richard Blundell is Leverhulme Research Professor of Economics at University College, London, and research director at the Institute for Fiscal Studies (IFS). Costas Meghir is professor of economics at University College, London, and deputy director of the Economic and Social Research Council (ESRC) Research Centre at the IFS. Sarah Smith is a lecturer at the London School of Economics and a research associate at the IFS. She worked on the project while at the IFS.

This paper forms part of the International Social Security project at the National Bureau of Economic Research (NBER). The authors are grateful to Jon Gruber, David Wise, and the participants of that project, and to Richard Disney and Paul Johnson for comments. The Department of Social Security is thanked for financing the primary analysis of the second wave of the Retirement Survey and for making the data available. Both waves of the Retirement Survey are now deposited at the ESRC Data Archive at the University of Essex. This research of part of the program of research by the ESRC Centre for the Micro-Economic Analysis of Public Policy at IFS, and we are grateful to the ESRC for funding. 

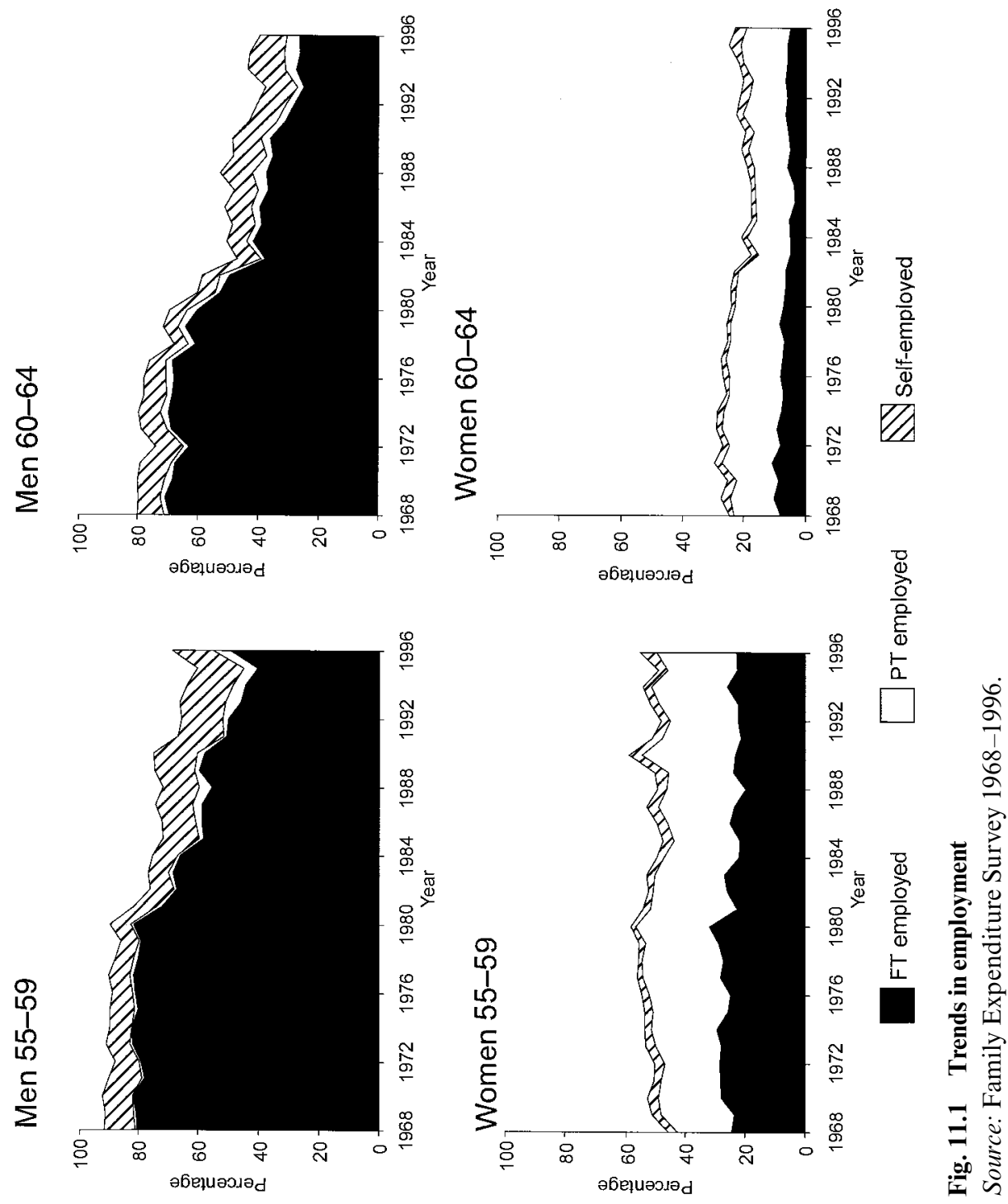
pensions provided by the state, but also on employer-provided pensions and on other state benefits, such as invalidity benefit, all of which have played a crucial role in the United Kingdom. Compared to many other European countries, the United Kingdom stands out as having a high level of coverage by private pensions and, at least in recent years, a trend towards less generous state pension provision.

This has not always been the case. In the 1970s, the trend was going the other way toward more generous state provision. The main element of the state pension system, the basic state pension, was increased each year in line with earnings or prices, whichever was the greatest. In 1978, a new second-tier earnings-related pension - the State Earnings Related Pension Scheme (SERPS) - was introduced that was originally intended to pay a pension worth 25 percent of an individual's best twenty years of earnings. However, SERPS was never a universal scheme for all employees. When it was introduced, workers who already belonged to a (defined-benefit) occupational pension could opt out of the state scheme, as well as pay reduced National Insurance contributions, so long as their occupational scheme guaranteed at least the same pension as SERPS. This applied to more than half of all employees and to more than two-thirds of male employees.

Since the early 1980 s, successive reforms have cut back the generosity of state pension provision. The indexation of the basic state pension to earnings lasted only until 1982, since when it has been formally indexed to prices and has fallen relative to average earnings. Reforms to SERPS in 1986 and 1995 have reduced its generosity for anyone retiring after 2000. Also, the state pension age for women, currently sixty, is set to increase to sixty-five by 2020 . These reforms were coupled with further encouragement for individuals to make a private pension provision. In 1988, the right to opt out of SERPS was extended to those with a defined-contribution scheme. In practice, this meant a growth in individual retirement accounts (personal pensions) and the development of defined-contribution occupational pensions, although these are still a minority of all employer schemes. The growth in personal pensions was rapid. By the early 1990s, they covered nearly one-quarter of employees and an even higher proportion of younger workers.

The trend towards less generous state pension provision means that, in spite of an aging population, the future cost of the state pensions is set to fall as a proportion of the gross domestic product (GDP) by 2050 (see table 11.1), making the situation in the United Kingdom different to most other OECD countries. ${ }^{1}$

However, it is worth bearing in mind that spending on pensions represents only part of total government spending on benefits for older 
Table 11.1 Projected State Spending on Pensions in the United Kingdom

\begin{tabular}{ccccccc}
\hline & 2000 & 2010 & 2020 & 2030 & 2040 & 2050 \\
\hline$\%$ of GDP & 4.5 & 5.2 & 5.1 & 5.5 & 4.0 & 4.1 \\
\hline
\end{tabular}

Source: Banks and Emmerson (2000).

nonworkers. In the 1980s, there was a very large increase in the number of older nonworkers on disability benefits ${ }^{2}$ (see figure 11.2) and spending on these benefits has more than doubled in real terms since 1990. Also, as the level of the basic state pension has now fallen below the level of meanstested benefits for pensioners, many pensioners are eligible for means-tested benefits on top of their state pension. By 2000-2001 more than one-third of pensioners were receiving means-tested benefits. Means testing is becoming an increasingly important element in state provision for pensioners with the introduction of an earnings-indexed means-tested Minimum Income Guarantee for pensioners from April 1999.

In this paper, we consider a cohort of workers retiring at the beginning of the 1990s and study the impact of the incentives in public and private pension schemes on their retirement. This cohort was in employment when coverage of defined-benefit occupational pensions was at its peak. Most men in the cohort belonged to an occupational pension scheme, and this is likely to be the key financial determinant of when they retire. Previous analysis has shown clear differences in the retirement behavior of people with and without occupational pensions - see Disney, Meghir, and Whitehouse (1994) and Blundell and Johnson (1998, 1999). Those with occupational pensions are more likely to remain in employment up to age sixty than those without, but are more likely to leave after this age (see figure 11.3). This difference in behavior has been attributed to the incentive structure of occupational pensions, but this has never been modeled explicitly. This paper therefore represents an important contribution to increasing understanding of the incentive effects of occupational pensions on retirement.

The state pension scheme is likely to have a smaller incentive effect on retirement behavior in the United Kingdom than that in other countries. The earnings-related element (SERPS) was adopted only in 1978 and is of relatively smaller magnitude than in other European countries. It will also be irrelevant to those people who opted out into occupational pension or personal pension schemes (and to many married women who opted out of the state pension system altogether). Only a minority of people in our sample of retirees remained in SERPS, although they form an interesting group to look at since SERPS was nearing its peak in terms of generosity at the time they were retiring.

2. The main benefit was invalidity benefit, which was replaced by incapacity benefit in 1995 . 


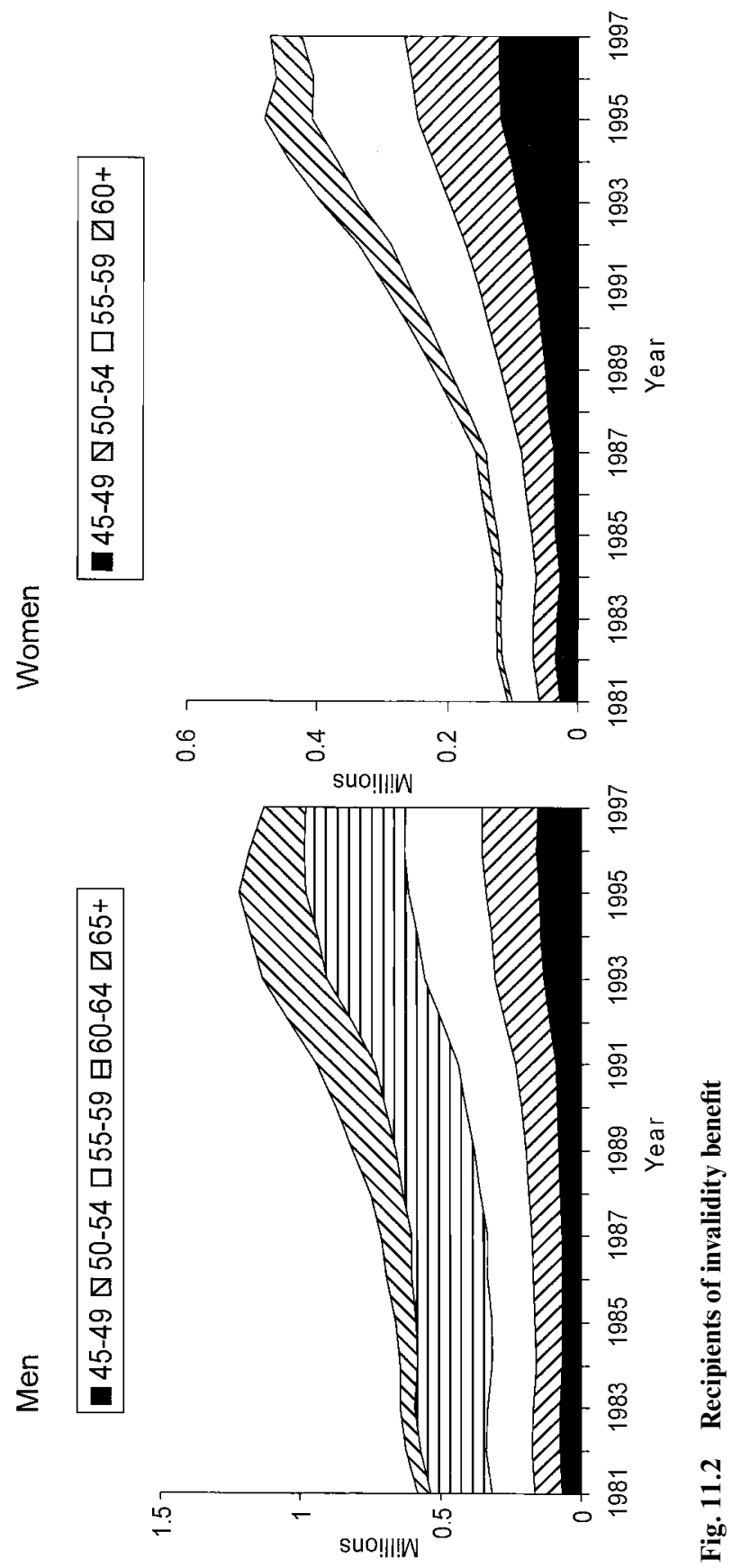



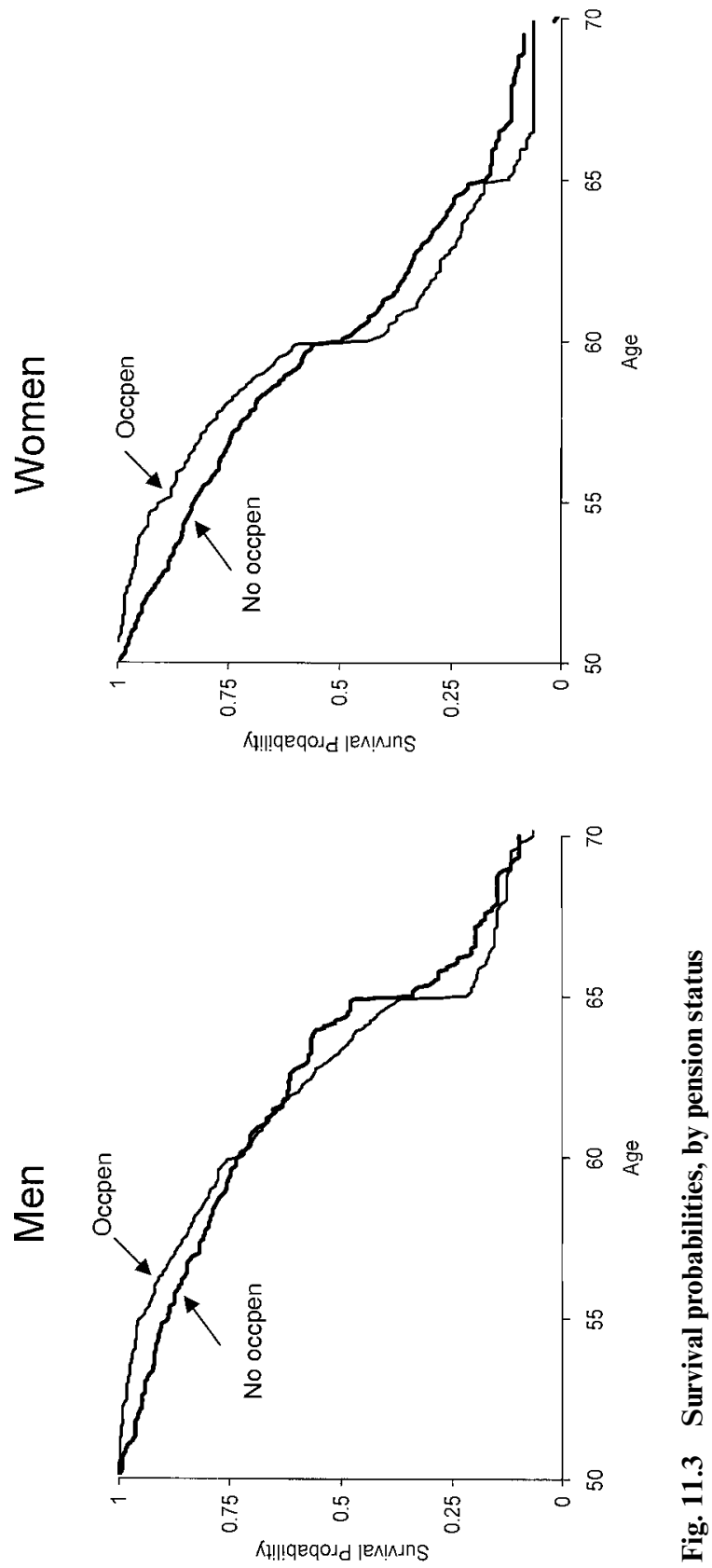
This paper models retirement incentives for the cohort of individuals in the U.K. Retirement Survey (Department of Social Security and Office for Population and Census Surveys, various years). This is a two-wave panel survey of a sample of individuals born between 1919 and 1933. The first wave, conducted between November 1988 and January 1989, collected information on 3,543 key respondents then aged fifty-five to sixty-nine. About two-thirds of the original sample were reinterviewed in 1994. The Retirement Survey has a larger sample of individuals in the relevant age range than any general household or individual surveys in the United Kingdom and is therefore the best currently available data for analyzing retirement behavior. However, it is considerably smaller than the administrative data sets used in other countries' studies. It also lacks complete earnings histories and full information on the rules of individuals' occupational pension schemes. Instead, we match earnings profiles from crosssectional surveys on the basis of cohort, education, and industry. We also model the individual's occupational pension entitlement according to the rules of the most common scheme in the sector that the individual works in.

The plan of the paper is as follows. The next section describes the U.K. pension system and the key elements that are likely to affect retirement behavior. Section 11.3 provides further information on the Retirement Survey and the selection criteria that we use for choosing a sample of individuals for analyzing retirement behavior. Section 11.4 describes the construction of earnings- and pension-incentive measures. Section 11.5 contains the results from estimating probit models of retirement that include these incentive measures and discusses their implications for retirement behavior by means of alternative scenarios for reforms to the pension system. In section 11.6, we present simulation results from two policy reforms designed to reduce the incentives for early retirement in the current pension system. Section 11.7 concludes.

\subsection{Policy Environment}

The U.K. pension system is two-tiered. The first tier, provided by the state, consists of the basic state pension and a significant level of meanstested benefits (made more significant by the introduction of the Minimum Income Guarantee for pensioners in April 1999). The second tier, compulsory for all employees with earnings above a certain floor, is made up of the SERPS $^{3}$ and a large and growing level of private provision (see figure 11.4).

3. The SERPS will be replaced by the state second pension from 2002 . This will effectively be a flat-rate top-up to the basic state pension and more generous than SERPS to low earners. Most workers will be encouraged to opt out into private provision. 


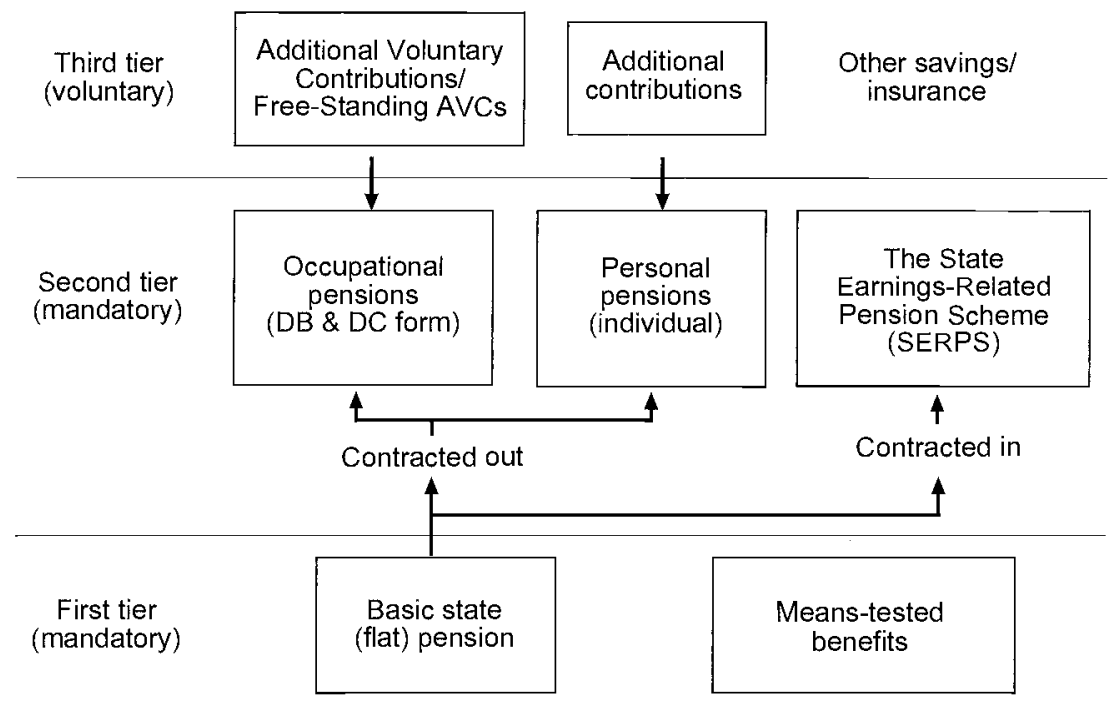

Fig. 11.4 U.K. pension system, 1990

\subsubsection{The Basic State Pension}

The basic state pension is a flat-rate contributory benefit payable to people aged over the state pension age (sixty-five for men and sixty for women ${ }^{4}$ ) who have made sufficient contributions throughout their working lives. ${ }^{5}$ From April 2000, the basic state pension is worth $£ 72.50$ a week for a single pensioner. Prior to 1978, married women could opt to pay a reduced rate of National Insurance, which meant they did not qualify for a basic state pension in their own right. Couples in which one partner does not qualify for the basic state pension receive a dependent addition, irrespective of whether they have ever worked or not. Since 1989, there has been no earnings test for receipt of the basic state pension, ${ }^{6}$ although individuals who choose to defer will increase the value of their pension by 10 percent for each year of deferral. ${ }^{7}$

\subsubsection{The State Earnings Related Pension Scheme (SERPS)}

The first part of the second tier of pension provision is the SERPS. Introduced in 1978, this pays a pension equal to a fraction of an individual's

4. The retirement age for women will be raised by six months each year from 2010 to 2020 so that equalization is achieved in 2020.

5. To qualify for the basic state pension, individuals need to have made or be credited with National Insurance contributions for 90 percent of their working lives. Credits are available for periods of illness, disability, or unemployment.

6. See Disney and Smith (2002) for a discussion of the effects of the abolition of the earnings test on labor supply.

7. Increased from 7.5 percent in 1995. 
qualifying annual earnings (above a specified lower-earnings limit) each year since 1978. When it was introduced, SERPS was intended to pay a pension worth one-quarter of an individual's best twenty years' earnings (up to a specified upper-earnings limit). Subsequent reductions in the generosity of SERPS mean that it is worth only 20 percent of average lifetime earnings to anyone retiring after 2000. Married women who opted to pay reduced-rate National Insurance contributions do not qualify for SERPS. Currently widows can claim their husbands' SERPS pensions in full if they receive no additional pension in their own right. ${ }^{8}$ After retirement the SERPS pension is uprated each year in line with prices.

\subsubsection{Income Support and Invalidity Benefit}

In addition to the basic state pension and SERPS, there are two other state benefits that are taken up widely by older nonworkers-income support and incapacity benefit (formerly invalidity benefit). Income support is a flat-rate, noncontributory, means-tested benefit. It is paid automatically to people aged sixty or more who do not work. Unlike people in younger age groups, the over-sixties do not have to show that they are actively seeking work in order to qualify. From April 1999, income support for pensioners was renamed the Minimum Income Guarantee and made more generous with an increase in the level and a commitment to uprate in line with earnings, at least for the short to medium term.

Incapacity benefit (formerly invalidity benefit) is a contributory benefit paid to the long-term sick and disabled. In the case of invalidity benefit, an individual qualified on the basis of medical certificates from their general practitioner (GP) showing them to be incapable of the work that was "reasonable" to expect them to do (given their age, qualifications, and so forth). With the introduction of incapacity benefit in 1995, this was changed to a stricter "all work test" carried out by a doctor employed by the Benefits Agency Medical Service. The change from invalidity benefit to incapacity benefit was a response to very rapid growth in receipt during the 1980s. A key feature of incapacity benefit (and invalidity benefit) is that, before April 2001, it was not means tested and could be received in conjunction with private pension income (unlike income support). From April 2001, it will be means tested against occupational pension income.

\subsubsection{Occupational and Personal Pensions}

Compared to most other European countries, the United Kingdom has a high level of coverage of private pensions, including both occupational pensions and individual retirement accounts, known in the United King-

8. This was due to be reduced to half from April 2000. However the failure of the government to properly inform individuals of the change in entitlement led to the reform being delayed. 
Table 11.2 Occupational Schemes: Defined Benefit (DB) versus Defined Contribution (DC)

\begin{tabular}{lccc}
\hline & $\%$ Private-Sector Schemes & $\%$ Public-Sector Schemes & $\%$ All Schemes \\
\hline DB plans & 78 & 98 & 80 \\
DC plans & 16 & 2 & 14 \\
Hybrid & 6 & 0 & 6 \\
\hline
\end{tabular}

Source: National Association of Pension Funds (NAPF) 1998.

dom as personal pensions. Any individual can choose to contract out of SERPS, into one of these two types of secondary private pensions (and from April 2001, people are also able to choose to opt out into a stakeholder pension, which is effectively a benchmarked individual retirement account). Members of defined-benefit occupational schemes pay a reduced rate of National Insurance, while those with defined-contribution occupational pensions or personal pensions receive a National Insurance rebate paid directly into their fund.

Occupational pensions currently cover around 45 percent of employees, down from a peak of over 50 percent in the early 1980s. They are typically defined-benefit schemes (DB; see table 11.2), although since 1988, employees have also been allowed to opt out into defined contribution (DC) occupational schemes, and there has been a gradual shift from DB to DC schemes since then (see Disney and Stears 1996). The decline in coverage of occupational pension schemes is due to a number of factors. It reflects changing employment patterns and a shift to smaller employers. Also, it reflects increasing pension choice among individuals working for employers offering occupational pensions who, since 1988, can no longer be compelled to join the scheme.

Since 1988, individuals have been able to contract out of SERPS (and leave their occupational scheme) and take out a personal pension. To kick start these schemes when they were introduced, a bonus National Insurance contribution of 2 percent was paid by the government, in addition to the contracted-out rebate. By the mid-1990s, around 6 million people (more than one-quarter of all employees) had taken out a personal pension. Takeup was higher among younger workers, as would be expected. However, there is a serious issue over the number of older workers who were "missold" personal pensions by financial advisers who wrongly advised them that they would be better off leaving their occupational pension scheme.

Table 11.3 summarizes labor market participation and income receipt by age using data from the Family Expenditure Survey 1994-1995 (corresponding to the second wave of the Retirement Survey). It shows relatively high rates of labor market withdrawal among men before the state pension age. The two most important sources of income before state pension age are income from private (predominantly occupational) pensions and disability benefit. It is important to stress that these two sources of income are not al- 


\begin{tabular}{ccccccccc}
\hline $\begin{array}{c}\text { Gender } \\
\text { and Age }\end{array}$ & $\begin{array}{c}\text { Full-Time } \\
\text { Work }\end{array}$ & $\begin{array}{c}\text { Part-Time } \\
\text { Work }\end{array}$ & $\begin{array}{c}\text { Not } \\
\text { Working }\end{array}$ & $\begin{array}{c}\text { Public } \\
\text { Pension }\end{array}$ & $\begin{array}{c}\text { Private } \\
\text { Pension }\end{array}$ & $\begin{array}{c}\text { Disability } \\
\text { Benefits }\end{array}$ & $\begin{array}{c}\text { Disability } \\
\text { Benefits } \\
\text { + Private }\end{array}$ & $\begin{array}{c}\text { Other } \\
\text { Benefits }\end{array}$ \\
\hline Men & & & & & & & & \\
$50-54$ & 0.6447 & 0.2053 & 0.1500 & 0.0000 & 0.0947 & 0.0737 & 0.0237 & 0.0658 \\
$55-59$ & 0.4620 & 0.1881 & 0.3598 & 0.0000 & 0.3432 & 0.1386 & 0.0825 & 0.0728 \\
$60-64$ & 0.2680 & 0.1787 & 0.5533 & 0.0000 & 0.5395 & 0.2096 & 0.1478 & 0.1237 \\
$65-69$ & 0.0213 & 0.0816 & 0.8972 & 0.8121 & 0.7411 & 0.1667 & 0.1312 & 0.0532 \\
Women & & & & & & & & \\
$50-54$ & 0.4667 & 0.2427 & 0.2907 & 0.0507 & 0.1040 & 0.0400 & 0.0133 & 0.0480 \\
$55-59$ & 0.2936 & 0.2385 & 0.4679 & 0.0975 & 0.1988 & 0.0398 & 0.0061 & 0.0520 \\
$60-64$ & 0.0909 & 0.1394 & 0.7697 & 0.7970 & 0.3606 & 0.0242 & 0.0152 & 0.0485 \\
$65-69$ & 0.0156 & 0.0688 & 0.9156 & 0.9594 & 0.4125 & 0.0000 & 0.0000 & 0.0469 \\
\hline
\end{tabular}

Source: Family Expenditure Survey 1994-1995 (U.K. Data Archives, 1996).

ways alternative preretirement income sources, but are typically received together by the same people. The fact that disability benefit was not means tested meant that it could be received in conjunction with other forms of income. Three-quarters of people in receipt of disability benefit income also received some money from a private pension.

\subsection{Data Overview}

\subsubsection{The Retirement Survey}

The main data used for analyzing retirement behavior are drawn from the U.K. Retirement Survey (RS), a household panel survey collected by the Office for Population and Census Surveys on behalf of the Department for Social Security. This is the first large-scale panel data set in the United Kingdom to focus on individuals around the time of retirement (see Bone et al. 1992). Two waves of data were collected on a national random sample of individuals born between 1919 and 1933. The first wave of the survey was conducted between November 1988 and January 1989 and collected information on 3,543 key respondents (who were aged fifty-five to sixtynine). The key respondents include spouses if they were in the relevant age range. In addition, information was also collected on 609 spouses outside this age range. About two-thirds of the original sample were reinterviewed in 1994, and 11 percent of respondents disappeared in this interval due to mortality; the residual attrition is a combination of nonresponse and (perhaps) unreported mortality. ${ }^{9}$

9. The high attrition rate is largely due to the fact that the survey was not originally intended to be a panel survey. Hence, little attempt was made to keep in touch with respondents after the first wave. 
The RS offers a relatively large sample of people in the relevant age range, compared to more general panel surveys, such as the British Household Panel Survey. It also offers very rich demographic, economic, and health information on individuals - and their spouses - in both waves. And it has employment history information and private pension history information dating all the way back to individuals' first jobs. ${ }^{10}$ However, compared to the administrative datasets available in other countries, the sample in the RS is relatively small (and is reduced by the high attrition rate between the two waves). Also, the survey does not collect earnings-history information, which is needed to calculate exact pension entitlements for each individual. Instead, as we describe in the next section, we have to impute earnings histories on the basis of employment-history information.

The analysis of retirement behavior in this paper is based on a subsample of people in the RS. The group we look at comprises those who were

- below the state pension age in wave 1 , that is, men aged fifty-five to sixty-four or women aged fifty-five to fifty-nine in 1988-1989;

- working in wave 1 with nonmissing earnings information and no income from occupational pension schemes, unemployment benefit, or income support;

- and interviewed in both waves.

Excluding people who fail to meet any one of these criteria leaves 456 individuals - 283 men and 173 women. Each of these individuals remains in the sample from 1989 until they leave employment, leaving a total sample of 1,998 person observations. Summary sample characteristics based on all person observations are given in table 11.4.

\subsubsection{Earnings Histories and Projections}

To calculate state pension entitlements, we need individual earnings profiles going back to 1978, when SERPS was introduced. These are absent in the RS, but the survey does provide detailed work histories documenting spells in employment, whether the employment was part time or full time, and in which industry the individual worked, which, together with information on age and education, allow us to match earnings profiles from cross-sectional data. There is no single dataset with consistent information on these variables going back to 1978. Instead, we combine information from two datasets to get consecutive cross-sectional waves of data from 1978 to 1989- the Family Expenditure Survey (1978-1986) and the General Household Survey (1987-1989). Projecting forward from 1989, we assume constant real wages.

10. For a good overview of information in the RS (Department of Social Security and Office for Population and Census Surveys, various years), see Disney, Grundy, and Johnson (1998). 


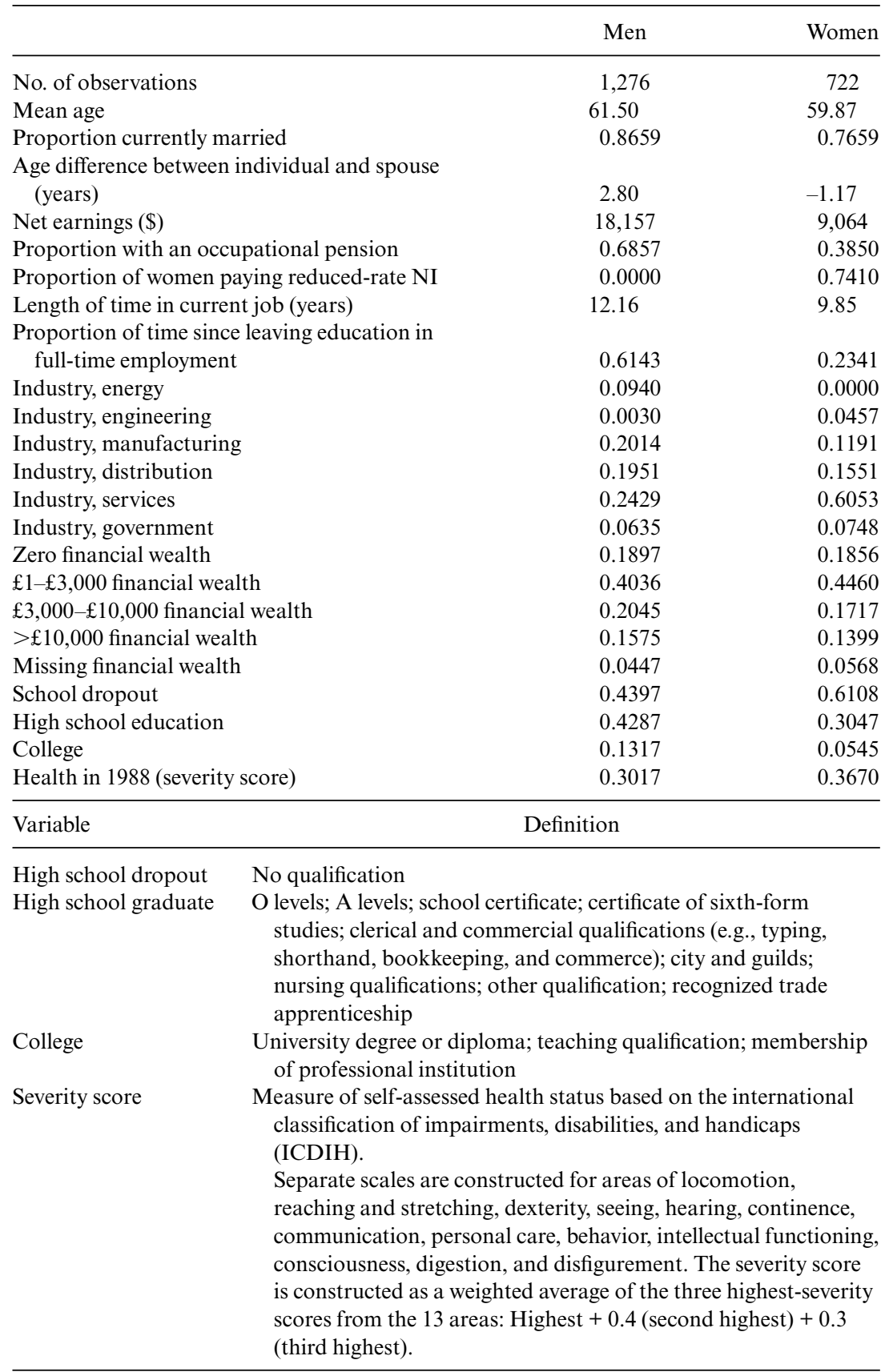

Note: $\mathrm{NI}=$ National Insurance; FT $=$ Full-time 
We also exploit the earnings information that is available in the first wave of the RS to construct an individual fixed effect, which we use to adjust the individual's entire earnings profile. We assume that the wage of individual $i$ in cohort, education, and industry subgroup $g$ in period $t$ can be expressed as

$$
W_{i g t}=\theta_{i} W_{g t}
$$

where $\theta_{i}$ is a constant individual fixed effect, $W_{i g 88} / W_{g 88}$, where $W_{i g 88}$ is taken from the RS and $W_{g 88}$ is calculated from the cross-sectional data. Our underlying assumption is that macro-shocks affect everyone in the cohort, education, and industry subgroup in the same way.

\subsection{Construction of Incentive Measures}

Each individual's total pension wealth and pension accrual measures are built up from combining four separate elements of the pension system-the basic state pension, the state earnings-related scheme (SERPS), occupational pensions, and invalidity benefit. ${ }^{11}$ In this section, we discuss how each of these individual elements is constructed. We also discuss potential sources of variation in total pension wealth and accrual rates by which we might identify the impact of pension incentives on retirement behavior.

\subsubsection{The Basic State Pension}

Calculation of basic state pension entitlement is straightforward. It depends on the total number of years of contribution and, for a married woman, on whether or not she opted to pay reduced-rate National Insurance contributions. This latter piece of information is known directly from the RS.

Although the basic state pension is flat rate, total wealth will vary across individuals because of the dependent's allowance and because of the fact that widows not entitled to a pension in their own right can claim their former spouse's pension in full when their spouse dies. In these cases, we need to compute husbands' total pension wealth over the life of the couple, based on the age difference between the spouses. Obviously, the larger the age difference between husband and wife, the greater the husband's total pension wealth.

\subsubsection{State Earnings Related Pension Scheme}

The precise formula for calculating an individual's SERPS pension is given by

$$
\text { SERPS }=\sum_{t=1978}^{R}\left(\tilde{W}_{t} \frac{Y_{R}}{Y_{t}}-\mathrm{LEL}_{R-1}\right) \chi_{R t}, \quad \text { where } \tilde{W}_{t}=\min \left(W_{t}, \mathrm{UEL}\right) .
$$

11. We ignore income support since it is a universal benefit. 
Earnings up to the annual upper-earnings limit (UEL) are revalued to the year of reaching state pension age $(R)$ using an index of economy-wide average earnings $\left(Y_{R} / Y_{t}\right)$. The lower-earnings limit (LEL) in the year prior to the individual reaching state pension age is deducted from each year's revalued earnings figure and the net of LEL earnings are multiplied by an accrual factor $\left(\chi_{R t}\right) \cdot{ }^{12}$ For people retiring before 2000, the accrual rate was 1.25 percent a year. Details of earnings factors, upper- and lower-earnings limits, and accrual rates are given by table 11A.1 in the appendix. Having calculated earnings profiles for each individual in the RS, their SERPS entitlements are fairly straightforward to calculate. We assume zero SERPS pension for people who are in occupational pension schemes and for married women who have opted to pay reduced-rate National Insurance contributions.

There are several potential sources of variation in SERPS pension wealth across individuals. Total wealth, but not accrual, will be affected by an individual's employment history since 1978 - both the number of years they have been in employment and their earnings - while projected earnings in the future will have an impact on expected total wealth and accrual. Another important factor for determining total wealth (but not accrual) will be the individual's age in 1978. This was when SERPS was introduced and an individual's age in that year will determine the period over which they are able to accrue rights to a SERPS pension before reaching state pension age. The maximum SERPS pension to which an individual could be entitled, for each year of retirement since 1978 is shown in figure 11.5 (and also the SERPS entitlement based on average earnings). For example, someone reaching state pension age in 1979 would receive practically no SERPS pension since they would only have been building up entitlement for one year. ${ }^{13}$ Someone retiring in 1998 could have accrued rights to a SERPS pension of up to $£ 5,000$ a year by earning the upper-earnings limit for twenty years.

As shown in table 11A.1, accrual rates will change after 2000, but this reform will not affect the cohort of individuals in the RS, all of whom will have reached the state pension age before then. Finally, the fact that widows can claim their former husbands' SERPS pensions if they receive no pension in their own right means that, as with the basic state pension, a man's marital status, and the age difference between them and their spouse also affects their total pension wealth and accrual.

Table 11.5 compares our estimates of individuals' SERPS pension with the actual SERPS pension they received where this information is available

12. Starting April 2000 this formula changes. Instead of uprating annual earnings and then subtracting the LEL from the year prior to retirement, the LEL from the year worked is subtracted from earnings first, and then the difference is uprated in line with earnings growth. Since the LEL is annually uprated in line with the basic state pension (i.e., with prices), this has the effect of reducing the generosity of SERPS.

13. Individuals cease to build up entitlements once they pass the state pension age. 


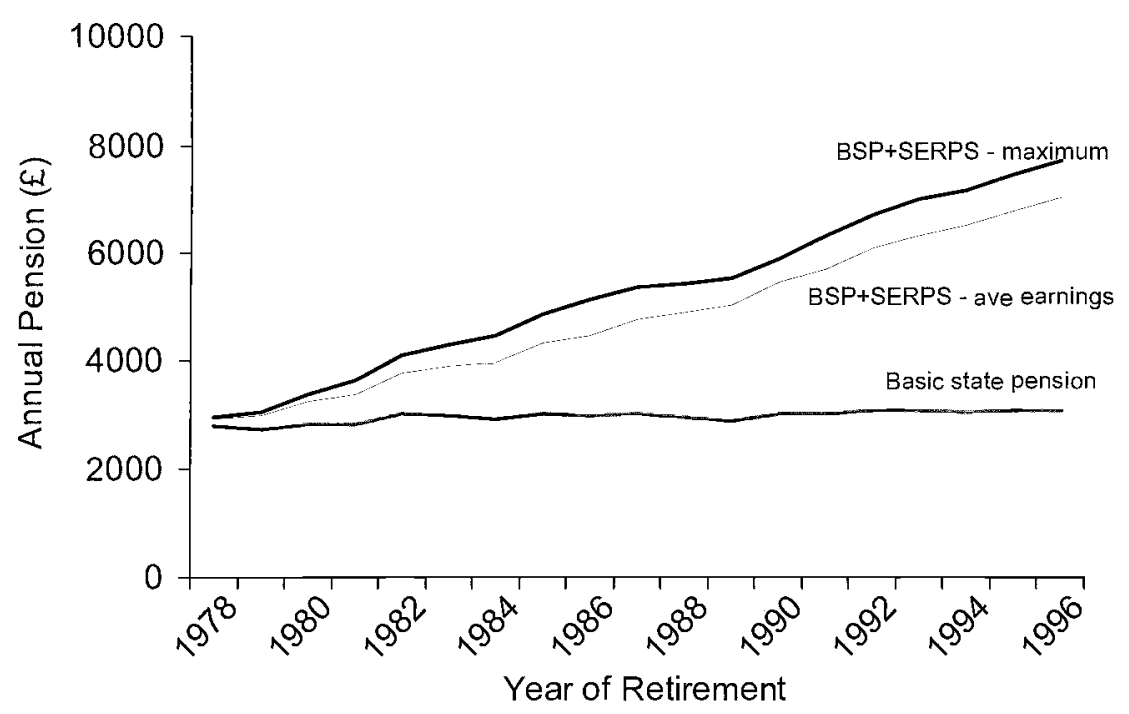

Fig. 11.5 SERPS entitlement

Predicted and Actual SERPS Pensions

Actual SERPS pension received in 1994 (\$)

(i.e., for individuals who had retired by the second wave of the RS and reported pension receipt). On average, we underpredict individuals' SERPS pensions, and while the correlation coefficient is positive and significant, it is fairly low, compared to that for occupational pensions (see following discussion). One possible explanation is that individuals who are in SERPSand therefore not in occupational pension schemes - are likely to have had more variable employment histories than those who are in occupational schemes. Our method for estimating earnings profiles may be missing a lot of variation in their previous earnings, which would also matter more for SERPS than for occupational pensions that are typically determined only according to recent years' earnings.

\subsubsection{Invalidity Benefit}

One possible way to treat entitlement to invalidity benefit would be to assume that only individuals who received the benefit were eligible and that all those who satisfied the eligibility conditions received the benefit. However, given the potential for subjective evaluations of "incapacity for work" 
and "reasonable work" and in the light of significant variation in the number of people receiving the benefit over time (as well as anecdotal evidence of differences between doctors in their willingness to certify individuals as being incapable of work), this assumption is inappropriate. Instead, we calculate an individual's invalidity-benefit wealth on the basis of an assigned probability that they will receive the benefit. These probabilities are derived from a probit model for receipt of invalidity benefit as a function of characteristics such as age, education, region, tenure, marital status, and spouse's employment status, which we estimate using data drawn from the Family Expenditure Survey from April 1988 to March 1994. We impute probabilities for individuals in the RS on the basis of matched characteristics. The probit results are reported in appendix table 11A.2.

\subsubsection{Occupational Pensions}

The pension received in a DB occupational pension scheme is typically determined by a formula of the type:

$$
P=\chi\left(P E_{R}-\beta \mathrm{LEL}_{R-1}\right) N,
$$

where $P$ is the annual occupational pension, $\chi$ is the scheme-specific accrual rate, $P E_{R}$ is pensionable earnings at the time of retirement (which are typically the individual's average earnings in the last year or last few years before retirement), $\beta$ is the integration factor, and $N$ is the number of years that the individual has belonged to the scheme. From information in the RS, we know $N$, the number of years the individual has belonged to the scheme. However, we have to make reasonable assumptions about $\chi_{R t}$, $P E_{R}$, and $\beta$.

The key distinction that we make is between individuals who work in the public sector versus those in the private sector. We assume that different typical schemes apply in the two sectors with different accrual rates, definitions of pensionable earnings, and integration factors. This assumption, and the choice of parameter values that we adopt, are based on information from the 1997 (NAPF) Survey of Occupational Pension Funds (1998), which shows a clear difference between public and private sector schemes (see table 11.6).

We assume an accrual rate of one-sixtieth for private sector and oneeightieth for public sector. For pensionable earnings, we take the best three out of last ten years' earnings for individuals working in the private sector and the best single year's earnings out of the last ten years for individuals working in the public sector. We assume an integration factor of 1 for private-sector schemes and 0 for public-sector schemes.

By construction, total occupational pension wealth-and accrual rates - will vary across individuals according to whether they work in the public or private sector. But there are other sources of variation in both total wealth and accrual rates. Total wealth will vary according to the num- 
Table 11.6

Private versus Public Schemes

\begin{tabular}{|c|c|c|}
\hline & Private Schemes (\%) & Public Schemes (\%) \\
\hline \multicolumn{3}{|c|}{ Accrual Rates } \\
\hline $1 / 80$ th & 15 & 92 \\
\hline $1 / 60$ th & 65 & 8 \\
\hline Other & 20 & 0 \\
\hline \multicolumn{3}{|c|}{ Definition of Pensionable Earnings } \\
\hline Actual earnings at retirement & 11 & 2 \\
\hline Actual earnings at fixed date & 4 & 3 \\
\hline Average earnings over the last 12 months & 23 & 9 \\
\hline Best year's earnings within $3-10$ years & 25 & 86 \\
\hline Best 3 years' earnings within $10-13$ years & 30 & \\
\hline Other & 7 & \\
\hline \multicolumn{3}{|c|}{ Integration With State Schemes } \\
\hline \multicolumn{3}{|l|}{ Integration } \\
\hline No & 44 & 92 \\
\hline Yes & 56 & 8 \\
\hline \multicolumn{3}{|l|}{ Adjustment based on: } \\
\hline Basic state pension & 43 & 50 \\
\hline Lower earnings limit & 55 & 50 \\
\hline Other & 2 & \\
\hline
\end{tabular}

Source: NAPF (1998).

ber of years that the individual has belonged to the scheme, while projected earnings in the future will have an impact on expected total wealth and accrual.

Further variation in accrual rates comes from differences across occupational schemes in the age at which individuals are entitled to start drawing their pension, which is also asked in the RS. ${ }^{14}$ We assume that people can continue to accrue rights to occupational pensions beyond this age (up to a maximum of forty years), but for each year that they continue to work beyond this age, they lose a year's pension. This is clearly a simplification of the actual rules of occupational pension schemes, and not least because, around this time, many firms implemented early retirement schemes to encourage exits. With no information about the availability of these schemes in the RS, we are almost certain not to capture the actual set of retirement incentives facing some individuals. Even so, we do appear to estimate fairly well the level of occupational pension income received in retirement. Table 11.7 compares our estimates of individuals' occupational pension with the actual occupational pension they received, where this information is available (i.e., for individuals who had retired by the second wave of the RS and

14. The survey asks "at what age will you start to receive the pension," and then asks "is that the usual age for drawing a pension," which is true for 90 percent of respondents. Where information on usual pension age is missing, we assume that it is sixty-five (the modal age). 
Table 11.7

Predicted and Actual Occupational Pensions

Actual occupational pension received in 1994 (\$)

8,140

Imputed occupational pension in retirement year (\$)

7,762

Correlation coefficient

0.7868

No. of observations

172

Table 11.8

Sources of Variation in Pension Incentives Across Individuals

\begin{tabular}{llcc}
\hline & & Wealth & Accrual \\
\hline Marital status and age of spouse (survivor's benefits) & BSP, SERPS, OP & $\checkmark$ & $\checkmark$ \\
Whether paid reduced-rate NI (married women) & BSP, SERPS & $\checkmark$ & $\checkmark$ \\
Whether spouse paid reduced-rate NI (married men) & BSP, SERPS & $\checkmark$ & $\checkmark$ \\
Past earnings & SERPS, OP & $\checkmark$ & \\
Future earnings & SERPS, OP & & $\checkmark$ \\
Date of birth & SERPS & $\checkmark$ & \\
Number of years with current employer & OP & $\checkmark$ & $\checkmark$ \\
Accrual rate-SERPS, public sector, private sector & OP & $\checkmark$ & $\checkmark$ \\
Pensionable earnings—-public sector, private sector & OP & $\checkmark$ & $\checkmark$ \\
Normal retirement age & OP & $\checkmark$ & $\checkmark$ \\
Region, tenure, spouse's employment, education, age & IVB & $\checkmark$ \\
\hline
\end{tabular}

Note $:$ BSP = basic state pension; $\mathrm{OP}=$ occupational pension; $\mathrm{IVB}=$ invalidity benefit.

reported pension receipt). As with SERPS, we underpredict individuals' total level of occupational pension income, but the correlation coefficient is positive, significant, and high.

\subsubsection{Total Pension Wealth and Accrual Measures}

Identifying the effects of incentive measures on retirement behavior requires these measures to vary across individuals, over time, or both, conditional on the other sociodemographic covariates that would be included in a model of retirement. As the previous discussion of the construction of the pension incentive measures has shown, there are a number of potential sources of variation in total wealth and in the forward-looking accrual measures for each of the four separate elements of the pension system. Table 11.8 summarizes these sources of variation, indicating which of the four elements of the system - the basic state pension, SERPS, occupational pension, and invalidity benefit - is affected and whether the source drives variation in total pension wealth or forward-looking accrual measures (or both). Almost all of the sources of variation affect both total pension wealth and accrual. However, future earnings will affect forwardlooking accrual measures but not current total pension wealth, while total wealth (but not accrual) varies with past earnings and with the individual's date of birth (in the case of individuals with SERPS). 
In our analysis of the incentive effects of pensions on retirement, three different forward-looking measures of accrual are used. The first is simply the one-period accrual - that is, how much an individual can add to their total pension wealth by working this period. The second is peak value. This represents the difference between total pension wealth accumulated by the start of the period and the maximum total pension wealth an individual could accumulate looking forward across all future years. This is a more appropriate measure if it is assumed that labor market exits by older workers are irreversible. In this case, when someone leaves the labor market, they are giving up all possible future additions to their pension and will therefore consider how much they could increase their pension by staying in the labor market not just for this period, but in all future periods. By not retiring now, individuals retain an option to retire in the future and, thereby, to increase their pension. This is very similar in spirit to the option value (Stock and Wise 1990), which is the third measure used.

In the option value model, individuals are assumed to compare the value of retiring now to the maximum of the expected values of retiring at all future ages, where the value of retiring at future ages includes both possible pension additions and future earnings, that is,

$$
\mathrm{OV}=V_{t}\left(r^{*}\right)-V_{t}(t) \quad \text { where } V_{t}(r)=\sum_{s=t}^{r-1} \beta^{s-t} Y_{s}^{\gamma}+\sum_{s=r}^{T} \beta^{s-t}\left[k B_{s}(r)\right]^{\gamma},
$$

where $Y_{s}$ is earnings and $B_{s}$ retirement benefits. The option value differs from the peak value by incorporating the future value of earnings until retirement and by incorporating utility parameters $k$, the differential value of income in leisure compared to earned income, and $\gamma$, the coefficient of relative risk aversion. In our calculation of option values we assume $k=1.50$ and $\gamma=0.75$. We assume a discount factor $(\beta)$ of 0.97 throughout.

Tables 11.9-11.11 summarizes the distribution of pension incentive measures for men and women by age. These are calculated across all men and women of the same age who remain in our sample (i.e., those who have not yet exited the labor force) and will therefore be affected by differential selection into the sample at each age. All the figures are expressed in 1998 prices and in dollars. ${ }^{15}$

Table 11.9 summarizes pension incentive measures for men, pooling those with and without an occupational pension. There is a clear effect of the state pension age — sixty-five for men — on the incentive measures. For men over sixty-five, median accruals are negative and total pension wealth starts to fall. ${ }^{16}$ It is worth pointing out that the selection effects will tend to increase average accrual measures - and reduce average total wealth-

15. Assuming an exchange rate of $\$ 1.50$ to $£ 1$.

16. Individuals can choose to defer their pension after the state pension ages. However, since deferral is actuarially unfair for an average male and with no earnings test, we assume that all men start to draw their state pension at age sixty-five. 
Incentive Measures for Men (\$1998 prices)

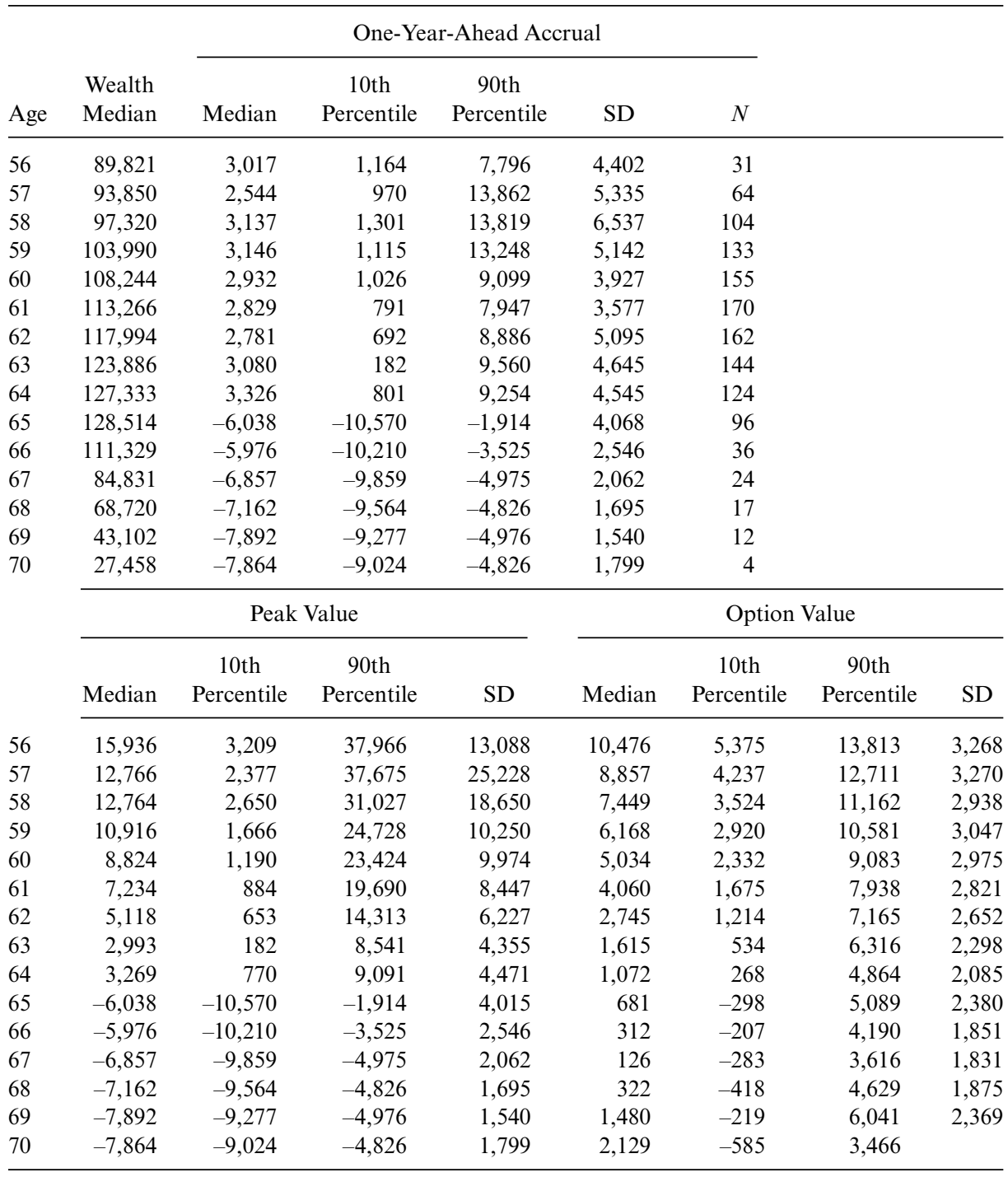

Notes: $\mathrm{SD}=$ standard deviation; $N=$ number of observations.

since those with lower accrual rates and higher total wealth will tend to exit the labor market earlier and so drop out of the sample.

The peak values and option values yield more pronounced incentives for people to stay in work at younger ages than the single period accruals. The median option values remain positive up to age seventy, reflecting relatively low replacement rates in the United Kingdom. With the assumption that real earnings remain constant indefinitely, this appears to create an in- 
Table 11.10

Incentive Measures for Men With or Without Occupational Pension

$(\$, 1998$ price

\begin{tabular}{|c|c|c|c|c|c|c|}
\hline \multirow[b]{2}{*}{ Age } & \multirow[b]{2}{*}{ Median Wealth } & \multicolumn{2}{|c|}{ Peak Value } & \multicolumn{2}{|c|}{ Option Value } & \multirow[b]{2}{*}{$N$} \\
\hline & & Median & SD & Median & SD & \\
\hline \multicolumn{7}{|c|}{ With Occupational Pension } \\
\hline 56 & 89,813 & 20,617 & 12,318 & 11,060 & 2,429 & 22 \\
\hline 57 & 94,818 & 16,313 & 28,814 & 9,509 & 2,873 & 44 \\
\hline 58 & 100,479 & 15,433 & 20,429 & 8,128 & 2,745 & 77 \\
\hline 59 & 106,350 & 12,622 & 10,697 & 7,041 & 3,042 & 95 \\
\hline 60 & 111,982 & 10,424 & 10,793 & 5,858 & 3,098 & 112 \\
\hline 61 & 115,244 & 8,406 & 9,287 & 4,898 & 2,984 & 123 \\
\hline 62 & 119,875 & 6,407 & 6,956 & 3,742 & 2,858 & 113 \\
\hline 63 & 129,065 & 3,932 & 4,940 & 2,443 & 2,466 & 102 \\
\hline 64 & 129,262 & 4,906 & 5,033 & 1,301 & 2,326 & 86 \\
\hline 65 & 134,894 & $-4,710$ & 4,264 & 1,147 & 2,526 & 62 \\
\hline 66 & 120,887 & $-5,248$ & 1,630 & 1,795 & 1,941 & 18 \\
\hline 67 & 88,656 & $-6,300$ & 1,947 & 682 & 2,012 & 10 \\
\hline 68 & 73,094 & $-7,162$ & 1,622 & 340 & 1,760 & 7 \\
\hline 69 & 45,510 & $-7,785$ & 435 & 1,566 & 2,636 & 3 \\
\hline 70 & 28,010 & $-9,024$ & & 2,441 & & 1 \\
\hline \multicolumn{7}{|c|}{ Without Occupational Pension } \\
\hline 56 & 94,040 & 3,636 & 7,777 & 5,585 & 2,474 & 9 \\
\hline 57 & 81,424 & 4,374 & 6,166 & 4,976 & 2,488 & 20 \\
\hline 58 & 89,181 & 5,658 & 4,944 & 4,776 & 2,133 & 27 \\
\hline 59 & 92,931 & 4,403 & 4,931 & 4,002 & 1,756 & 38 \\
\hline 60 & 98,296 & 4,267 & 4,116 & 3,358 & 1,342 & 43 \\
\hline 61 & 105,402 & 3,949 & 3,277 & 2,543 & 1,129 & 47 \\
\hline 62 & 110,036 & 2,575 & 2,185 & 1,727 & 964 & 49 \\
\hline 63 & 116,857 & 1,373 & 1,145 & 863 & 573 & 42 \\
\hline 64 & 122,692 & 1,576 & 1,174 & 926 & 1,010 & 38 \\
\hline 65 & 126,471 & $-9,286$ & 2,314 & -45 & 1,104 & 34 \\
\hline 66 & 103,687 & $-8,614$ & 2,254 & -29 & 1,334 & 18 \\
\hline 67 & 82,364 & $-8,355$ & 1,915 & 43 & 1,708 & 14 \\
\hline 68 & 50,315 & $-7,550$ & 1,832 & 305 & 2,045 & 10 \\
\hline 69 & 41,864 & $-8,800$ & 1,772 & 1,394 & 2,387 & 9 \\
\hline 70 & 26,906 & $-7,760$ & 1,757 & 1,817 & 2,037 & 3 \\
\hline
\end{tabular}

Notes: $\mathrm{SD}=$ standard deviation; $N=$ number of observations.

centive for some individuals to carry on working even at older ages. This will be reinforced by increasing selection of high-wage individuals into the sample with age.

Table 11.10 compares the incentive measures for men with and without occupational pensions. Figure 11.3 showed a clear difference in the labor market exit behavior of these two groups; men with an occupational pension are more likely to stay in work at younger ages. Table 11.10 shows that men with occupational pensions tend to have higher median peak values and option values up to the state pension age, as well as higher wealth. These incentives could work toward either earlier or later retirement. The 
Incentive Measures for Women (\$1998 prices)

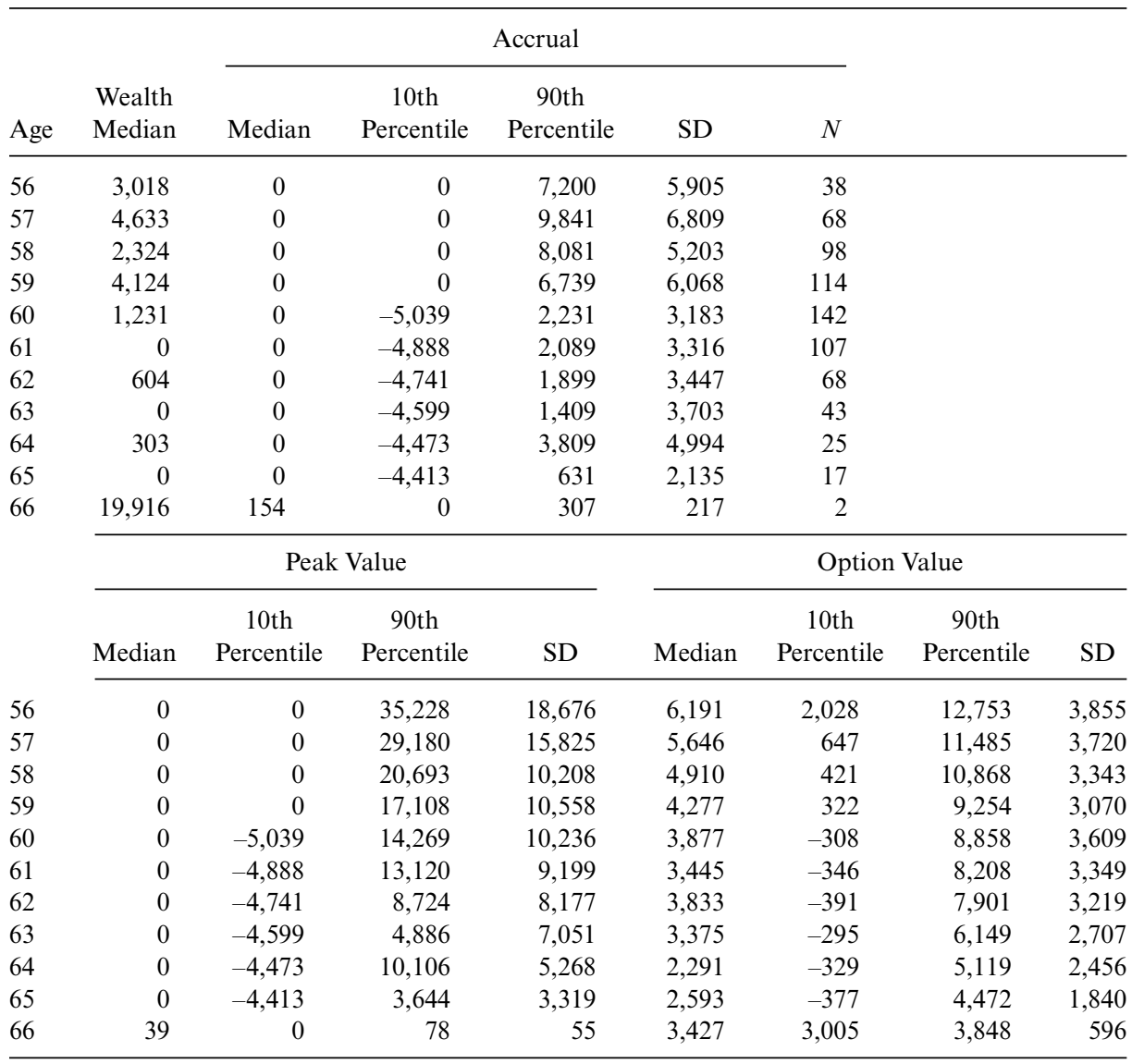

Notes: $\mathrm{SD}=$ standard deviation; $N=$ number of observations.

observed pattern of exits suggests that the effect of the higher option values is likely to dominate, at least at younger ages, encouraging men with occupational pensions to stay in employment. It is worth pointing out that although the typical annual occupational pension is considerably higher than the typical SERPS pension (comparing tables 11.5 and 11.7), the difference between total pension wealth for people with occupational pensions and those without is reduced by the more generous survivors' benefit provisions of SERPS. In the case of SERPS, the surviving spouse inherits the pension in full; in the case of occupational pensions, they inherit only half. ${ }^{17}$

Table 11.12 summarizes the incentive measures for women. The large

17. The survivors' benefit was due to be cut to half in SERPS from April 2001. However, in the build-up to the preannounced reform many people were issued the wrong information in the form of leaflets that did not refer to the reform. The change has been delayed to October 2002, and those who can show that they were misinformed will keep their original entitlement. 
The Probability of Male Retirement (1,276 observations)

\begin{tabular}{|c|c|c|c|c|c|c|}
\hline & \multicolumn{2}{|c|}{ Linear Age } & \multicolumn{2}{|c|}{ Cohort Dummies } & \multicolumn{2}{|c|}{ Age Dummies } \\
\hline & $\begin{array}{c}\text { Marginal } \\
\text { Effect }\end{array}$ & SE & $\begin{array}{c}\text { Marginal } \\
\text { Effect }\end{array}$ & $\mathrm{SE}$ & $\begin{array}{c}\text { Marginal } \\
\text { Effect }\end{array}$ & SE \\
\hline \multicolumn{7}{|c|}{ Single Period Accruals } \\
\hline Excluding age first eligible & & & & & & \\
\hline Pension wealth & .0999 & .0183 & .1158 & .0197 & .0915 & .0196 \\
\hline Single-period accrual & -.4975 & .1574 & -.8890 & .1513 & -.1251 & .1761 \\
\hline Spouse wealth & .0324 & .0154 & .0386 & .0164 & .0305 & .0159 \\
\hline Pseudo $R^{2}$ & .1961 & & .1885 & & .2352 & \\
\hline Log-likelihood & -404.11 & & -407.93 & & -384.43 & \\
\hline$F$ test (PW, Accrual) & 34.59 & & 60.44 & & 21.43 & \\
\hline \multicolumn{7}{|l|}{ Including age first eligible } \\
\hline Pension wealth & .0699 & .0188 & .0861 & .0206 & .0825 & .0201 \\
\hline Single-period accrual & -.1954 & .1623 & -.6365 & .1580 & -.1144 & .1769 \\
\hline Spouse wealth & .0224 & .0155 & .0281 & .0166 & .0278 & .0158 \\
\hline Penage dummy & .1787 & .0453 & .1586 & .0455 & & \\
\hline Pseudo $R^{2}$ & .2235 & & .2087 & & .2386 & \\
\hline Log-likelihood & -390.33 & & -397.77 & & -382.72 & \\
\hline$F$ test (PW, Accrual) & 13.50 & & 26.67 & & 16.68 & \\
\hline \multicolumn{7}{|c|}{ Peak Value } \\
\hline \multicolumn{7}{|l|}{ Excluding age first eligible } \\
\hline Pension wealth & .0883 & .0173 & .0999 & .0192 & .0892 & .0192 \\
\hline Peak accrual & -.0946 & .0795 & -.3170 & .0780 & -.0257 & .0574 \\
\hline Spouse wealth & .0296 & .0152 & .0297 & .0166 & .0293 & .0157 \\
\hline Pseudo $R^{2}$ & .1866 & & .1670 & & .2348 & \\
\hline Log-likelihood & -408.88 & & -418.71 & & -384.62 & \\
\hline$F$ test (PW, Accrual) & 25.81 & & 40.54 & & 21.10 & \\
\hline \multicolumn{7}{|l|}{ Including age first eligible } \\
\hline Pension wealth & .0629 & .0178 & .0696 & .0198 & .0802 & .0197 \\
\hline Peak accrual & .0084 & .0765 & -.2025 & .0786 & -.0115 & .0760 \\
\hline Spouse wealth & .0194 & .0153 & .0199 & .0167 & .0266 & .0157 \\
\hline Penage dummy & .1991 & .0452 & .2012 & .0471 & .0962 & .0636 \\
\hline Pseudo $R^{2}$ & .2220 & & .1987 & & .2382 & \\
\hline Log-likelihood & -391.07 & & -402.77 & & -382.92 & \\
\hline$F$ test (PW, Accrual) & 12.09 & & 16.75 & & 16.33 & \\
\hline
\end{tabular}

number of zeros arises as a result of the number of married women who are not eligible for a pension in their own right. This means that the median single-period accruals and median peak accruals are all equal to zero. As with men, the effect of the state pension age is clear, with the tenth percentile single-period accruals and peak values turning negative at age sixty. The ninetieth percentile peak values and option values remain positive after this age because of occupational pension schemes, which may have normal pension ages for women that are actually higher for women than their state pension age. 
(continued)

\begin{tabular}{|c|c|c|c|c|c|c|}
\hline & \multicolumn{2}{|c|}{ Linear Age } & \multicolumn{2}{|c|}{ Cohort Dummies } & \multicolumn{2}{|c|}{ Age Dummies } \\
\hline & $\begin{array}{c}\text { Marginal } \\
\text { Effect }\end{array}$ & SE & $\begin{array}{l}\text { Marginal } \\
\text { Effect }\end{array}$ & SE & $\begin{array}{l}\text { Marginal } \\
\text { Effect }\end{array}$ & SE \\
\hline \multicolumn{7}{|c|}{ Option Value } \\
\hline \multicolumn{7}{|c|}{ Excluding age first eligible } \\
\hline Pension wealth & 0.7706 & .0205 & .0509 & .0206 & .0750 & .0213 \\
\hline Option value & -.3619 & .4196 & -1.7598 & .3675 & -.6140 & .4462 \\
\hline Spouse wealth & .0244 & .0153 & .0188 & .0165 & .0267 & .0158 \\
\hline Pseudo $R^{2}$ & .1858 & & .1731 & & .2366 & \\
\hline Log-likelihood & -409.25 & & -415.68 & & -383.72 & \\
\hline$F$ test (PW, Accrual) & 25.06 & & 44.58 & & 22.71 & \\
\hline \multicolumn{7}{|c|}{ Including age first eligible } \\
\hline Pension wealth & .0531 & .0209 & .0246 & .0209 & .0654 & .0218 \\
\hline Option value & -.3739 & .4201 & -1.5893 & .3653 & -.6397 & .4460 \\
\hline Spouse wealth & .0175 & .0154 & .0105 & .0164 & .0239 & .0157 \\
\hline Penage dummy & .1977 & .0440 & .2142 & .0465 & .0995 & .0637 \\
\hline Pseudo $R^{2}$ & .2228 & & .2111 & & .2403 & \\
\hline Log-likelihood & -390.68 & & -396.54 & & -381.88 & \\
\hline$F$ test (PW, Accrual) & 12.78 & & 27.43 & & 18.19 & \\
\hline
\end{tabular}

Notes: The full set of demographic controls include earnings (and earnings squared), education, health, job tenure, industry, proportion of time spent in full-time employment, whether individual has an occupational pension, housing tenure, financial wealth, age difference within couples, spouse's earnings, spouse's health, and whether spouse is retired. $\mathrm{PW}=$ pension wealth; $\mathrm{SE}=$ standard error.

\subsection{Estimated Pension Incentives and the Probability of Retirement}

\subsubsection{The Statistical Model}

We estimate the impact of the incentive and wealth variables on retirement decisions by modeling the conditional probability of exit from employment for individuals in the RS.

For each individual $i$, we write $D_{i t}=1$ if the individual has left the labor market in period $t$ (conditional on being in the labor market in period $t-$ 1). The probability of this event is then modeled as a function of observable household and individual characteristics, as well as the pension incentive variables. The pension incentive variables, defined in the previous section, are discounted wealth, option value (or single-period accrual), spouse's pension wealth, and the pension age. The latter measures the earliest age at which someone can draw their pension. This varies not only across gender, but also across type of pension plan. Denoting the observable characteristics as $Z_{i t}$, and the pension incentive variables as $I_{i t}$, our conditional probability model may be expressed as

$$
\operatorname{Pr}\left(D_{i t}=1\right)=G\left(a^{\prime} Z_{i t}+b^{\prime} I_{i t}\right)
$$


where $G$ is the cumulative distribution function of unobservables in the conditional exit model and $a$ and $b$ are unknown response coefficients.

In estimation, we assume $G$ is a cumulative standard normal and consequently estimate $a$ and $b$ using a probit model for the conditional exit probability, pooled over all five years of retirement information in the RS. In constructing the standard errors, we need to allow for dependence over time in the unobservables for the same individual in the panel who survives more than one period before retiring. This is implemented using the block bootstrap method.

\subsubsection{The Impact on Retirement}

The discussion in section 11.4 has highlighted the sources of variation in the pension incentive variables. We argue that there is sufficient variability in the pension variables, conditional on the full set of other variables included in the regressions. Generally it is difficult to gauge how much variation one needs for a credible estimate-after all, this crucially depends on the amount of variance in the errors. However, we note that, for our most general specification, 40 percent of total pension wealth in the case of men and 43 percent of total pension wealth in the case of women remains unexplained by all the other included regressors, including option values (see table 11A.3 in appendix). For the option value, 24 percent of that for men and 32 percent of that for women remains unexplained by the other regressors, including total pension wealth. Overall, the pension variables, conditional on our functional form assumptions and exclusion restrictions, seem to display sufficient variability.

Turning to the conditional exit probability estimates, table 11.12 presents the marginal effects and standard errors from a probit regression for a variety of specifications estimated using data on our sample of men in the RS. Table 11.13 provides the equivalent estimates for women. The results are separated into three panels (single accrual, peak value, and option value) according to the specification of the incentive variable. These are precisely as defined in the previous section and, in particular, allow for the basic pension, SERPS, and occupational schemes where the individual is eligible. They also allow for eligibility to invalidity benefit according to the assigned probability model described in section 11.4.3.

The columns in each panel differ according to the specification of age effects. In the first column, a linear age term is allowed. It may be that all other age effects are simply due to the wealth and pension incentives, in which case this specification will be adequate. However, given that we are mixing different date of birth cohorts in this survey and that age effects may represent preferences as well as incentives, the next two columns allow for alternative age specifications. The second column includes a date-of-birthcohort dummy and the final column includes a full set of age dummies.

Each panel is further separated according to whether a dummy for the 
The Probability of Female Retirement (722 observations)

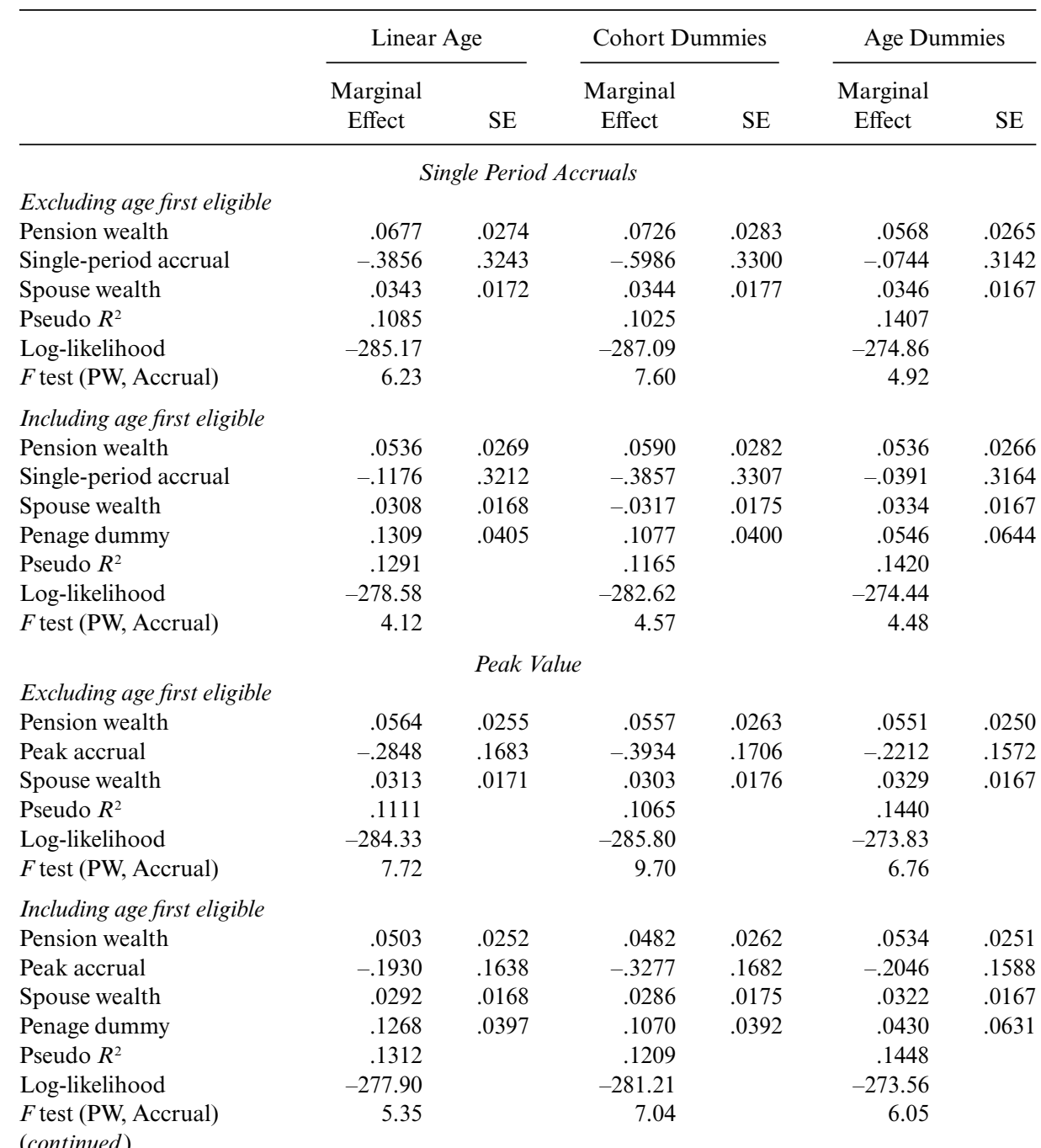

age at which individuals become eligible to receive a pension is includedthe "pension age." For recipients of the basic state pension and SERPS, this is the normal state pension age (sixty-five for men and sixty for women). For individuals with an occupational pension, we use the age at which they are entitled to start drawing their occupational pension. ${ }^{18}$ This

18. The results presented in the tables in this section focus only on the pension measures. A full result for a limited number of specifications are presented in table 11A.3. For example, table 11A.5 shows the effect of other demographic and economic characteristics on the probability of retirement. 
Table 11.13 (continued)

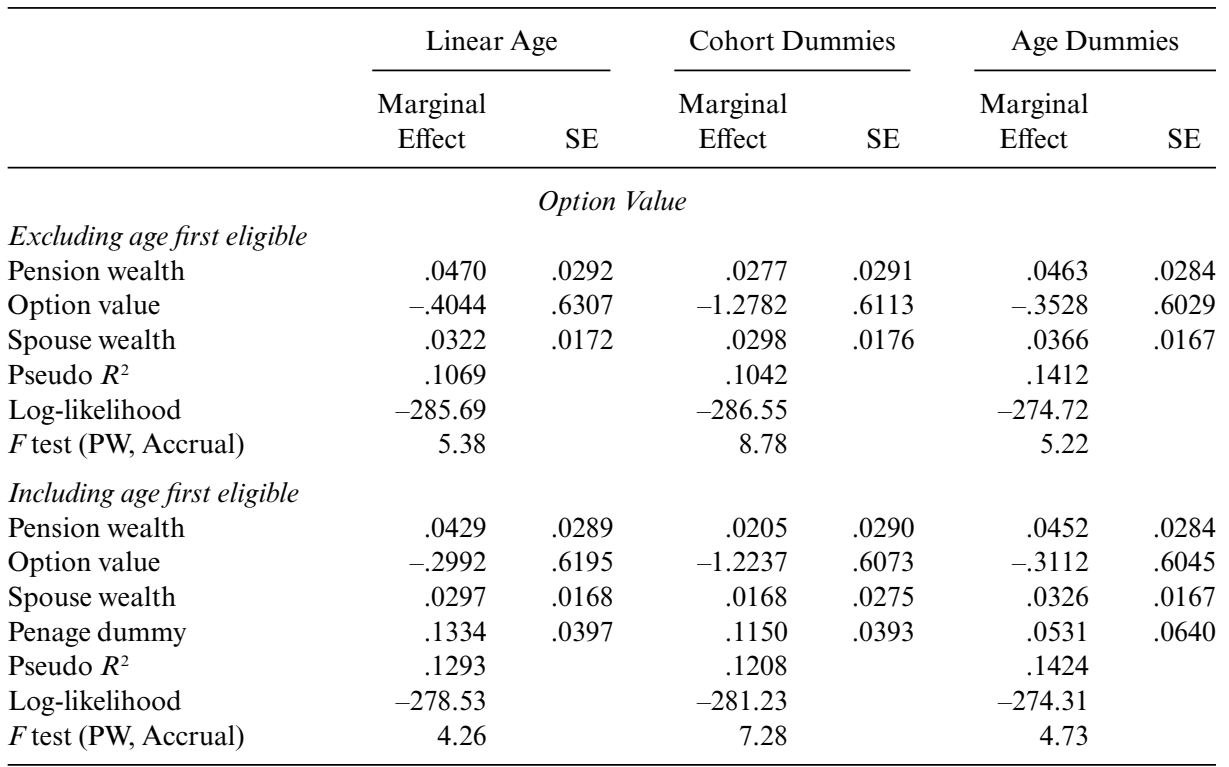

Note: The full set of demographic controls include earnings (and earnings squared), education, health, job tenure, industry, proportion of time spent in full-time employment, whether individual has an occupational pension, housing tenure, financial wealth, age difference within couples, spouse's earnings, spouse's health, and whether spouse is retired. $\mathrm{PW}=$ pension wealth; $\mathrm{SE}=$ standard error.

varies across individuals in occupational pension schemes so that it has potential explanatory power even when added to the specification with the full set of age dummies in the final column.

A broad look across the results in Table 11.12 is quite encouraging for the retirement model. In all cases, the pension wealth and incentive variables are jointly significant. In all but one of the eighteen specifications, the signs are as we would expect - a positive wealth effect and a negative accrual effect. These results are consistent with the presence of both income and substitution effects in retirement decisions. ${ }^{19}$ The positive coefficient on the total pension wealth variable points to an income effect, whereby individuals who accumulate a lot in earlier years retire earlier. The impact of the option value reflects future opportunities foregone by stopping working now; the negative coefficient on this term indicates that the greater those foregone opportunities, the less likely individuals are to retire. Since the incentive variables are measured in $\$ 100,000$, the coefficient of -0.6397 on the option value in the final column, for example, implies that a $\$ 10,000$ rise in the option values (leaving pension wealth unaffected) reduces the probability of retirement by a little over 6 percentage points. The counter-

19. The option value and total pension wealth measures are in hundred-thousands while net earnings are in thousands. 
factual simulations in the next section are intended to shed more light on what these magnitudes are likely to mean in reality.

The significance of these coefficients requires some discussion. The panel nature of the survey means that the standard errors calculated from the standard formula for the probit model will not account for the dependence across time periods. In table 11A.9, we present bootstrap confidence intervals that do allow for this dependence. Interestingly, these intervals maintain the significance found in the wealth and incentive variables in table 11.10 .

A more detailed examination of table 11.12 reveals some further interesting features. On pure likelihood grounds, the specifications that include the option value dominate specifications with the more ad hoc incentive variables. The dummy for the age at which the pension is first eligible is typically significant, although slightly less so for the option value specifications. The inclusion of date-of-birth-cohort effects, in the second column of each panel, tends to reduce the impact of the wealth variables. This seems consistent with the strong differences in wealth across cohorts. At the same time, it leads to a strong increase in the incentive variable. Indeed, for the peak value specifications, it is the only case where the incentive variable remains significant.

Including a completely unrestricted set of age effects reduces the magnitude of the substitution effect, although the wealth effect remains positive and significant. As we saw in the previous section, the option value has quite a lot of variation, even after including a full set of age effects. The estimates for the option value that also include the pension age dummy are the preferred (on the grounds of likelihood) and yield a marginally significant option value coefficient, albeit much reduced from the cohort dummy specification. Interestingly, the block bootstrap standard errors reported in table 11A.6 show a 95 percent interval that remains negative, suggesting a significant negative effect even in this specification with age effects and the pension age dummy.

Figure 11.6 compares the within-sample predictive performance of these model specifications. A number of immediate features stand out. First, even without including a full set of age dummies, we manage to predict a large amount of retirement before state pension age (sixty-five). This is due to the impact of invalidity benefit and early retirement incentives in the occupational systems. Second, the linear-age and cohort-effects specifications completely fail to capture the spike at sixty-five. Note that these specifications do not include the age first eligible to pension variable - we discuss this specification in more detail in our simulation of pension reforms. The linear-age effects specification does not manage to capture the downturn in retirement hazards that occurs after sixty-five.

The retirement model results for women, presented in table 11.13, are similar to those for men, although the magnitude of the coefficients is typically smaller. For the majority of women, their decision to continue working- 


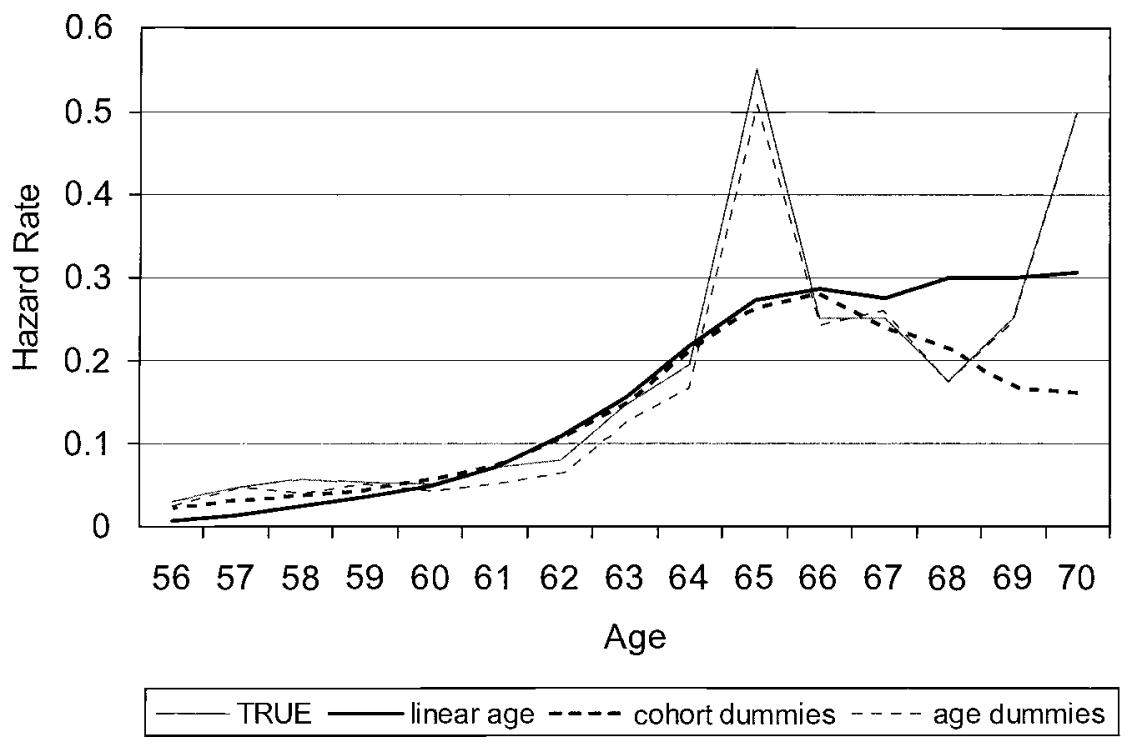

Fig. 11.6 Actual and predicted retirement hazards (option value)

and their decision to retire-is completely unaffected by the incentives in their own pension scheme, since they do not receive a pension in their own right. A lot of the identification of incentive effects is likely to come from exploiting variation between the set of women who do have their own pension and those who do not. In practice, however, these two groups of women are likely to differ in several other key respects, which makes it difficult to measure the pension incentive effects with a high degree of accuracy.

Very few of the other included demographic and economic variables are individually significant (see table 11A.5). Among those that are significant - for both men and women - are self-reported health status at the time of the first interview, the retirement status of the spouse (someone is more likely to retire if their spouse is already retired), and whether or not someone has an outstanding mortgage, which tends to reduce the probability of retirement. This is consistent with the idea that people might carry on working in order to pay off their mortgage. Typically, the occupational pension dummy is positive and significant. This might reflect unmeasured incentives arising from occupational pension rules or the fact that people tend to select jobs with occupational pension schemes according to their underlying preferences for early retirement.

\subsubsection{Evidence for Liquidity Constraints}

An interesting feature of the results in tables 11.12 and 11.13 is the significance of the pension age dummy. One possibility is that, prior to the age 
Table 11.14

Evidence of Liquidity Constraints (men)

\begin{tabular}{|c|c|c|c|c|c|c|}
\hline & $\begin{array}{c}\text { Marginal } \\
\text { Effect }\end{array}$ & SE & $\begin{array}{c}\text { Marginal } \\
\text { Effect }\end{array}$ & SE & $\begin{array}{l}\text { Marginal } \\
\text { Effect }\end{array}$ & SE \\
\hline \multicolumn{7}{|c|}{ All Men $(N=1,276)$} \\
\hline Pension wealth & .0282 & .0195 & .0371 & .0202 & & \\
\hline Option value & -1.5592 & .3650 & -.3572 & .4390 & & \\
\hline LiqPenW & & & -.0083 & .0195 & .0039 & .0190 \\
\hline LiqOV & & & -1.4586 & .3975 & -1.6173 & .3443 \\
\hline Log-likelihood & -397.33 & & -387.79 & & -390.63 & \\
\hline \multicolumn{7}{|c|}{ Financial Wealth $<£ 3,000(N=757)$} \\
\hline Pension wealth & -.0186 & .0255 & -.0096 & .0307 & & \\
\hline Option value & -2.3928 & .4741 & -1.7453 & .6182 & & \\
\hline LiqPenW & & & -.0012 & .0266 & -.0096 & .0241 \\
\hline $\mathrm{LiqOV}$ & & & -.6366 & .5145 & -1.5393 & .4244 \\
\hline Log-likelihood & -208.54 & & -207.07 & & -211.72 & \\
\hline \multicolumn{7}{|c|}{ With Occupational Pension $(N=875)$} \\
\hline Pension wealth & .0509 & .0239 & .0587 & .0250 & & \\
\hline Option value & -1.5178 & .4270 & -.1866 & .5295 & & \\
\hline LiqPenW & & & -.0102 & .0228 & .0060 & .0255 \\
\hline LiqOV & & & -1.7021 & .5054 & -1.8349 & .4317 \\
\hline Log-likelihood & -293.12 & & -285.33 & & -288.86 & \\
\hline \multicolumn{7}{|c|}{ With No Educational Qualifications ( $N=561$ ) } \\
\hline Pension wealth & -.0338 & .0597 & .0388 & .0655 & & \\
\hline Option value- -2.4158 & .7419 & -.1174 & .9399 & & & \\
\hline LiqPenW & & & -.0558 & .0595 & .0470 & .0568 \\
\hline LiqOV & & & -2.9933 & .9198 & -3.0554 & .7341 \\
\hline Log-likelihood & -184.33 & & -176.77 & & -177.10 & \\
\hline
\end{tabular}

Notes: Controls included for demographics, earnings, cohort dummies, and age of first entitlement to pension. $\mathrm{SE}=$ standard error; $N=$ number of observations.

at which individuals become entitled to start drawing their pension, they are liquidity constrained and unable to borrow against their future pension wealth, even if it is quite large. ${ }^{20}$ Reaching pension age and being able to start drawing their pension therefore may have a significant effect on the probability of retirement in addition to the incentive effects. Table 11.14 is an attempt to examine this.

The first panel considers the complete sample of men used in table 11.12 and includes two new variables- LiqPenW and LiqOV. These variables calculate wealth and incentives assuming that pension wealth only matters at the time the individual becomes entitled to start drawing on the pension income. Because individuals cannot directly draw on their wealth before this age, it is maybe assumed not to matter for retirement decisions. 
At first sight, this hypothesis seems quite plausible. However, the results presented in table 11.14 are mixed. The LiqPen W variable, which is where one might think the dominant impact of such an effect would occur, is never significant, and the original pension wealth variable always dominates. Perhaps the impact would be more important for those with smaller amounts of financial wealth. The second panel does not lend support to this. Here we just select those with financial wealth holdings less than $£ 3,000$. There is no noticeable impact of the liquidity measures of pension wealth.

Why should this be? One fact that we have pointed out is the low value of the state pension for most of those eligible for state pension. For many they will have their incomes in retirement topped up by welfare benefits. Moreover, if they retire before the state pension age, they will often be eligible for disability benefits and will receive an income much like the state pension. Their net incomes from employment as they age will stay quite stable and they have little reason to save or borrow. Moreover, since those eligible for state pension are typically lower skilled, their earnings in work are also quite low. The consequence is that their net replacement rates are little under 100 percent. Although they may implicitly face liquidity constraints, these are never binding and therefore have no impact on retirement decisions.

The remaining panels of table 11.14 further investigate the evidence for liquidity effects among those with occupational pensions and also those with lower educational qualifications. Again, in neither case is there much evidence that such constraints are binding on the retirement decision.

\subsection{Counterfactual Simulations}

To illustrate the size of the estimated incentive effects on retirement behavior, we consider the effects of reforms to the pension system on the predicted probabilities of retirement at different ages. Two alternative scenarios are considered.

The first counterfactual is to increase the pension age for everyone by three years. This means that the state pension age is sixty-eight for men and sixty-three for women. We also augment the normal occupational pension retirement ages by three years. There is clearly a correspondence in practice between the state pension ages and the normal retirement ages in occupational pension schemes, so increasing the state pension is likely to have a knock-on effect on occupational pension schemes. Moreover, the underlying demographic pressures that are likely to cause the government to reduce the generosity of the state pension system will have a similar effect on occupational schemes.

The second counterfactual assumes a pension system of the following form. 
- An early entitlement age of sixty

- A normal retirement age of sixty-five

- A 60 percent replacement rate at age sixty-five

- A 6 percent actuarial adjustment from sixty to seventy

- no other pathways to retirement

The effects of each of these alternative scenarios on the distribution of total pension wealth and option values by age are presented in table 11.15. We report results for men only since the majority of women, who have no pension in their own right, will be unaffected.

The effect of raising the retirement age is to reduce the median level of total pension wealth and to increase option values, compared to the existing pension system. The income and substitution effects work in the same direction, and the combined effect is to reduce the conditional probability of retirement at younger ages. The effects can most clearly be seen by plotting and comparing the predicted retirement probabilities under the base case of the existing pension system and under the reform. This is done in Figure 11.7, corresponding to the one-period accruals and option values respectively.

The precise magnitude of the effects of reforming the pension system depend on which specification is used. When a full set of age dummies is in-

Incentive Measures: The Impact of Reform (men, 1,272 observations)

\begin{tabular}{|c|c|c|c|c|c|c|}
\hline \multirow[b]{2}{*}{ Age } & \multicolumn{2}{|c|}{ Base } & \multicolumn{2}{|c|}{ Reform 1} & \multicolumn{2}{|c|}{ Reform 2} \\
\hline & $\begin{array}{l}\text { Median } \\
\text { TW }\end{array}$ & $\begin{array}{c}\text { Median } \\
\text { OV }\end{array}$ & $\begin{array}{l}\text { Median } \\
\text { TW }\end{array}$ & $\begin{array}{c}\text { Median } \\
\text { OV }\end{array}$ & $\begin{array}{l}\text { Median } \\
\text { TW }\end{array}$ & $\begin{array}{c}\text { Median } \\
\text { OV }\end{array}$ \\
\hline 56 & 89,821 & 10,476 & 76,862 & 13,353 & 102,841 & 13,660 \\
\hline 57 & 93,850 & 8,857 & 80,639 & 11,785 & 101,072 & 13,019 \\
\hline 58 & 97,320 & 7,449 & 83,564 & 10,320 & 105,531 & 12,880 \\
\hline 59 & 103,990 & 6,168 & 88,016 & 9,430 & 113,593 & 13,200 \\
\hline 60 & 108,244 & 5,034 & 90,293 & 8,084 & 116,247 & 13,384 \\
\hline 61 & 113,266 & 4,060 & 93,686 & 7,113 & 119,261 & 11,962 \\
\hline 62 & 117,994 & 2,745 & 97,107 & 6,046 & 118,727 & 11,112 \\
\hline 63 & 123,886 & 1,615 & 101,717 & 5,252 & 127,663 & 10,182 \\
\hline 64 & 127,333 & 1,072 & 103,070 & 4,229 & 125,523 & 9,768 \\
\hline 65 & 128,514 & 681 & 105,048 & 3,021 & 121,037 & 9,151 \\
\hline 66 & 111,329 & 312 & 114,466 & 1,544 & 131,675 & 8,332 \\
\hline 67 & 84,831 & 126 & 111,553 & 1,034 & 115,668 & 7,007 \\
\hline 68 & 68,720 & 322 & 109,707 & -119 & 115,164 & 6,211 \\
\hline 69 & 43,102 & 1,480 & 82,729 & -138 & 105,251 & 4,574 \\
\hline 70 & 27,458 & 2,129 & 67,553 & -217 & 71,404 & 2,990 \\
\hline
\end{tabular}

Notes: $\mathrm{OV}=$ option value; $\mathrm{TW}=$ total wealth. Reform 1 raises the pension age by three years; reform 2 introduced a pension system with a $60 \%$ replacement rate at the normal pension age of 65 , an early retirement age of 60 , and a $6 \%$ deferral rate. 

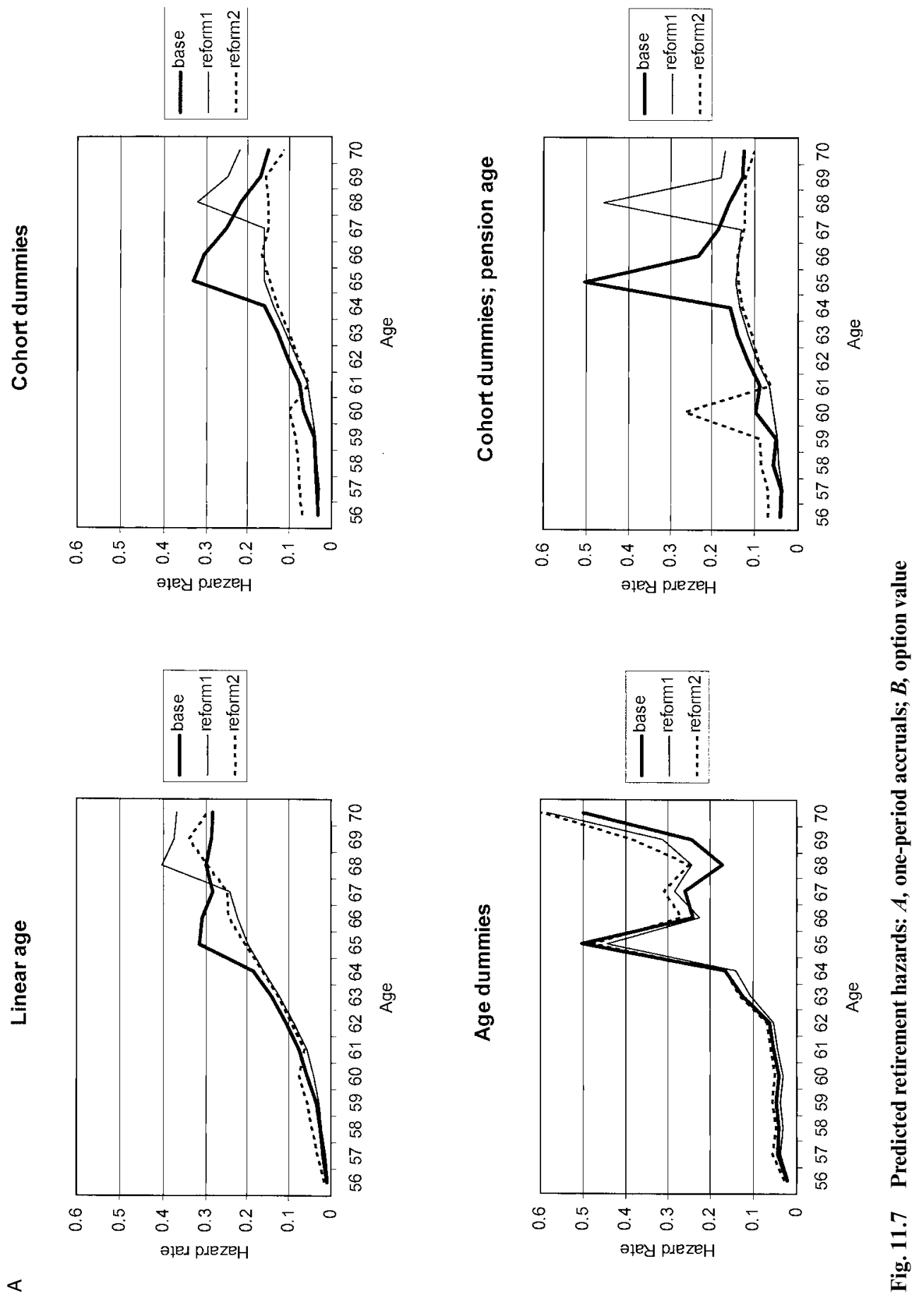

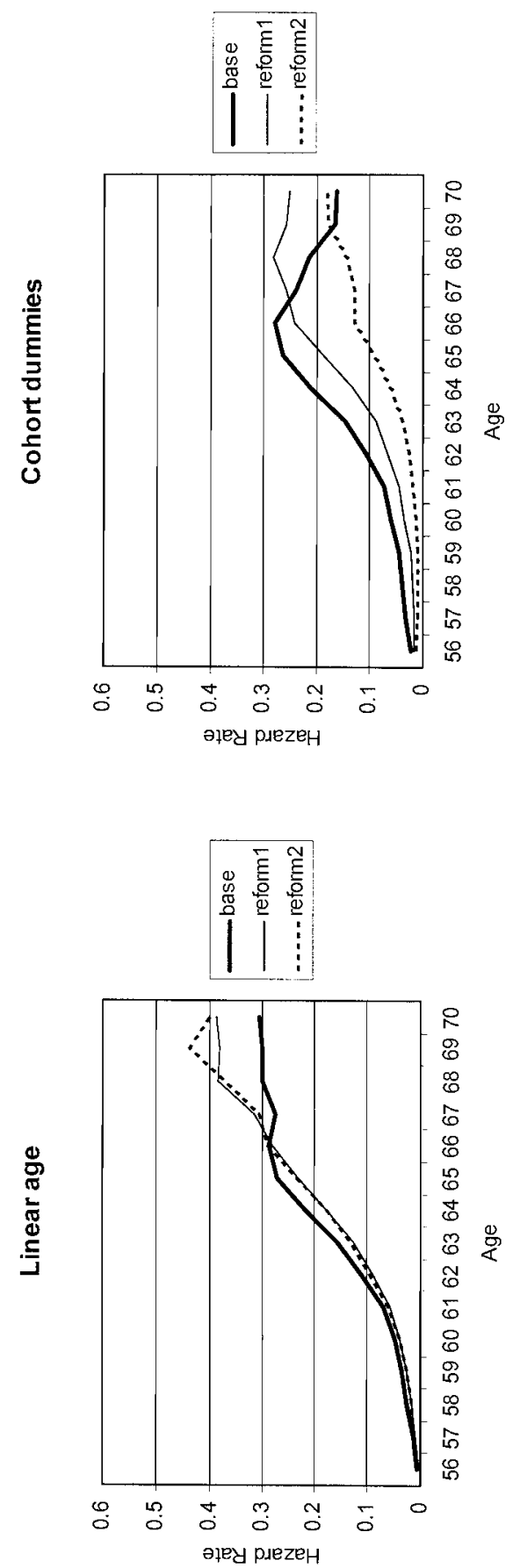
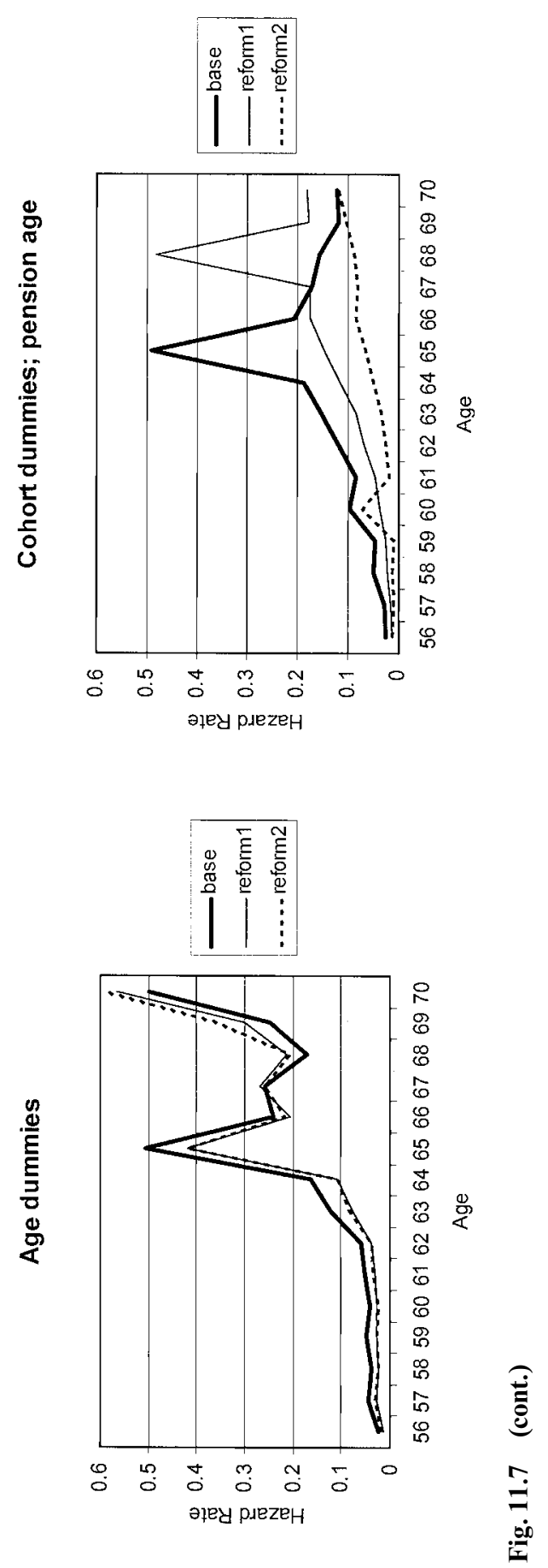
cluded these tend to dominate any of the pension wealth and accrual incentives and the effect of reforming the pension system appears to be very small. To the extent that the age dummies pick up the incentive effects, these would need to be adjusted to reflect the pivotal ages in the new system. The bottom-right-hand graph in figure 11.7 shows the effect of changing the "pension age."

When a set of cohort dummies is included, the effect of the forwardlooking accrual and option value measures is much stronger - as was seen from the regression results in the previous section, and this is reflected in bigger predicted responses from increasing the retirement age by three years. Looking at figure 7, panel A, which shows the retirement probabilities based on the one-period-ahead accrual, the effect is to halve the predicted probability of retirement at sixty-five. Including option values tends to smooth the effects over a longer period, as would be expected from a more forward-looking model. The probability of retirement is reduced by between 3-7 percentage points between the ages of sixty and sixty-six.

The effect of the second simulated reform is to increase the level of pension wealth and to increase the option values, compared to the existing system. Under the simulated reform, the level of annual pension income that the simulated pension system produces is relatively generous compared to the existing U.K. system. The option value effect is reinforced by the absence of any nonpension benefits (such as disability benefits) before retirement age under the simulated reform which increases the incentive to stay in work.

The effect on one-period accruals is slightly different and worth commenting on. Under the simulated reform, everyone is granted a full entitlement at age sixty and the level of pension is determined on the basis of earnings at age sixty-five. Therefore, the decision to continue working, before age sixty, has no effect on pension entitlement, and up until age sixty, the one-period-ahead accrual is zero. Only after age sixty is the one-period accrual positive (and higher than under the existing system). If the decision to leave work were reversible, then the optimal thing to do in terms of maximizing pension benefits might be to leave work until age sixty and then reenter to increase pension entitlements. The option value approach implicitly rules this out, and before age sixty gives a positive value to the option to increase pension value by working between sixty-one and sixty-two.

The effects of this can be seen from the simulated retirement probabilities in figure 11.7. Looking at the simulations with cohort dummies and the one-period-ahead accruals, the probability of retirement before age sixty is higher under the case of the second reform than it is in the base case. This reflects the higher level of pension wealth and the lower (effectively zero) accrual rate. After age sixty, however, the one-period accrual is positive and higher than under the existing system. The income and substitution effects now work in the opposite direction, with the substitution effect 
being more powerful; the probability of retirement is lower under the reform. The option value makes the higher substitution effect count at younger ages, and the probability of retirement is reduced at all ages.

\subsection{Summary and Conclusions}

The United Kingdom experienced a serious decline in labor market attachment among older workers in the 1980s and 1990s. This was especially acute among men aged fifty-five or older. The analysis we present shows that during the two recessions - the first in the early 1980s and the second in the early 1990s, the fraction of such men in employment declined by more than 30 percentage points to record-low levels of little over 50 percent and has shown no sign of recovery. For older women this decline was less evident, reflecting the growing participation rate among younger cohorts that offsets the decline in employment. To what extent can these low levels of labor market attachment be attributed to the workings of the U.K. pension system and to what extent can these trends be reversed by reforms to this system? These questions formed the motivation for this study.

We began the paper with a comprehensive evaluation of the economic incentives for retirement underlying the U.K. pension system. This accounted for the changing impact of the SERPS, introduced in 1978 and of growing importance for those retiring in the 1990s. It also accounted for the complex set of private defined-benefit occupation pension schemes, which provided coverage for nearly 70 percent of those approaching retirement in the 1990s. We highlighted the importance of invalidity benefit as a mechanism for income support in early retirement whose take-up approached nearly 1.5 million among individuals below state retirement age in the 1990s.

To examine the impact of these factors on retirement, we used a sample of individuals aged fifty-five or older from the U.K. RS. Their retirement probability was modeled in terms of the incentives underlying their own pension plans and other socioeconomic factors. Our analysis followed an option value approach and allows a separate role for pension wealth. We also allowed for the spouse's economic and demographic characteristics. The estimation results pointed to significant incentive and wealth effects through the pension system. The magnitude of these turned out to be quite sensitive to the specification of age effects. To allow for this, we considered three basic specifications. The first restricted age effects to enter linearly. This is clearly rejected by the data in favor of more general specifications but we retain it as a baseline specification. The second allowed for cohort effects, and the third allowed for a complete set of age dummies. Not surprisingly, the full set of age dummies was found to provide the best fit; but even in this case, the wealth and incentive variables remained correctly signed and significant. Overall the option value model performed better than models that used simpler and more ad hoc incentive measures. 
On their own, the incentive and pension wealth measures were unable to explain the large increase in the retirement at the normal retirement age (sixty-five for men and sixty for women). This explained the much improved fit of the age dummy specification. Nonetheless, the incentive and wealth variables alone managed to explain the most part of large amount of early retirement that occurs prior to the normal retirement age. This appeared to be due to a combination of the ability for invalidity benefit to act as an early retirement incentive and the significant incentives for early retirement that occur in occupational schemes in the United Kingdom. To explain the spike in the exit probability at the normal retirement age, we included a dummy for the age at which the individual could first draw down their pension. This variable was shown to contain variation over and above the age dummies because this age varied across occupational schemes. Even with this variable included, the option value incentive and pension wealth variables remained significant. We also investigated whether or not the significance of this variable could be attributed to a liquidity effectthat is, a wealth effect that only became important at the point at which the pension could be drawn. We found little success in this explanation.

Each of these specifications was used to simulate two policy reforms. The first - reform 1-involved an increase by three years in the pension age. The second - reform 2-was more complex. This later reform had an early retirement age at sixty with a normal retirement at age sixty-five. This was matched by a 60 percent replacement rate at sixty-five and a 6 percent actuarial adjustment from sixty to seventy. Finally, all other pathways to retirement were eliminated. Reform 1 had a clear impact on retirement in all specifications - moving the retirement peak to a later age and significantly cutting the incidence of early retirement. Reform 2 had an even more dramatic impact on early retirement, resulting in a smooth and lower rate of exit into retirement at all ages.

As a more cautious final note, it should be pointed out that the data source we used had a number of drawbacks. Most notably, the high attrition between waves and the resulting small sample size used in our analysis. In addition, many of the features of the occupational plans that we would like to include are missing from the data. More optimistically, the new English Longitudinal Survey of Ageing, which will produce the first wave in December 2003, will remedy both of these defects and will also provide a comprehensive and detailed data source on health and retirement. 


\section{Appendix}

Table 11A.1 Calculating SERPS using Accrual Rates, Earnings Factors, and Upper- and Lower-Earnings Limits (UEL, LEL, respectively)

\begin{tabular}{|c|c|c|c|c|c|}
\hline \multirow{2}{*}{ Year of Retirement } & & & \multicolumn{3}{|c|}{ Accrual Rate on Earnings } \\
\hline & & \multicolumn{2}{|c|}{ Between 1978-79 and 1987-88 } & \multicolumn{2}{|c|}{ 1988-89 Onwards } \\
\hline \multicolumn{2}{|l|}{ Before 1998-99 } & \multicolumn{2}{|c|}{$25-20=1.25$} & \multicolumn{2}{|c|}{$25-20=1.25$} \\
\hline $2000-01$ & & \multicolumn{2}{|c|}{$25-21=1.19$} & \multicolumn{2}{|c|}{$25-21=1.19$} \\
\hline 2005-06 & & \multicolumn{2}{|c|}{$25-26=0.96$} & \multicolumn{2}{|c|}{$22.5-26=0.87$} \\
\hline $2010-11$ & & \multicolumn{2}{|c|}{$25-31=0.81$} & \multicolumn{2}{|c|}{$20-31=0.65$} \\
\hline $2015-16$ & & \multicolumn{2}{|c|}{$25-36=0.69$} & \multicolumn{2}{|c|}{$20-36=0.56$} \\
\hline $2020-21$ & & \multicolumn{2}{|c|}{$25-41=0.61$} & \multicolumn{2}{|c|}{$20-41=0.49$} \\
\hline $2025-26$ & & \multicolumn{2}{|c|}{$25-46=0.54$} & \multicolumn{2}{|c|}{$20-46=0.431$} \\
\hline 2027-28 onwards & & \multicolumn{2}{|c|}{$25-49=0.51$} & \multicolumn{2}{|c|}{$20-49=0.41$} \\
\hline Year of Earnings & & Factor $(\%)$ & Year of Earnings & & Factor $(\%)$ \\
\hline $1978-79$ & & 377 & $1988-89$ & & 69.5 \\
\hline $1979-80$ & & 320.7 & 1989-90 & & 53.5 \\
\hline $1980-81$ & & 251.6 & 1990-91 & & 43.1 \\
\hline $1981-82$ & & 194.8 & $1991-92$ & & 30 \\
\hline $1982-83$ & & 167.6 & 1992-93 & & 22.1 \\
\hline $1983-84$ & & 148 & 1993-94 & & 16.3 \\
\hline $1984-85$ & & 129.6 & 1994-95 & & 11.7 \\
\hline $1985-86$ & & 115.5 & 1995-96 & & 8 \\
\hline $1986-87$ & & 97.9 & 1996-97 & & 5 \\
\hline $1987-88$ & & 84.4 & & & \\
\hline Year & LEL & UEL & Year & LEL & UEL \\
\hline $1978-79$ & 17.5 & 120 & $1988-89$ & 41 & 305 \\
\hline $1979-80$ & 19.5 & 135 & 1989-90 & 43 & 325 \\
\hline $1980-81$ & 23.0 & 165 & 1990-91 & 46 & 350 \\
\hline $1981-82$ & 27 & 200 & 1991-92 & 52 & 390 \\
\hline $1982-83$ & 29.5 & 220 & 1992-93 & 54 & 405 \\
\hline $1983-84$ & 32.5 & 235 & 1993-94 & 56 & 420 \\
\hline $1984-85$ & 34 & 250 & 1994-95 & 57 & 430 \\
\hline $1985-86$ & 35.5 & 265 & 1995-96 & 58 & 440 \\
\hline $1986-87$ & 38 & 285 & 1996-97 & 61 & 455 \\
\hline $1987-88$ & 39 & 295 & 1997-98 & 62 & 465 \\
\hline
\end{tabular}




\begin{tabular}{lccccc}
\hline & \multicolumn{2}{c}{ Men } & & \multicolumn{2}{c}{ Women } \\
\cline { 2 - 3 } \cline { 5 - 6 } & Coefficient & SE & & Coefficient & SE \\
\hline Yorks and Humberside & -.0958 & .0748 & & -.1601 & .1129 \\
Northwest & .0217 & .0713 & & .2176 & .0989 \\
East Midlands & -.4242 & .0857 & & -.2936 & .1256 \\
West Midlands & -.3005 & .0773 & & -.3128 & .1155 \\
East Anglia & -.6051 & .1189 & & -.4210 & .1700 \\
South East & -.5109 & .0835 & & -.2288 & .1165 \\
Greater London & -.5336 & .0731 & & -.4302 & .1101 \\
South West & -.4568 & .0852 & & -.3078 & .1253 \\
Wales & .2494 & .0809 & & .3606 & .1088 \\
Scotland & .0179 & .0743 & & .2237 & .0998 \\
Age & .5859 & .0246 & & .4968 & .0354 \\
Age & -.0054 & .0002 & & -.0048 & .0003 \\
College education & -.6891 & .0962 & & -.0452 & .1019 \\
Spouse employed & .1476 & .0416 & & -.1923 & .0467 \\
Homeowner with mortgage & .0109 & .0484 & & -.0529 & .0614 \\
Outright owner & -.0850 & .0399 & & -.2829 & .0595 \\
Constant & -15.7892 & .6933 & & -13.5498 & .9405 \\
No. of observations & 9,363 & & & 14,192 & \\
Pseudo $R^{2}$ & 0.2047 & & & 0.2013 & \\
\hline
\end{tabular}

Source: Data from the Family Expenditure Survey (U.K. Data Archive 1996) for the period from April 1988 to March 1994.

Note: $\mathrm{SE}=$ standard error. 
Dependent Variable

Total Pension Wealth

Accrual Peak Value Option Value

Option value

Total pension wealth

Spouse pension wealth

Difference in ages

Job tenure

$\%$ of full-time employment

Education

Health score

Spouse health score

Renter

Mortgage

Industry, engineering

Industry, manufacturing

Industry, distribution

Industry, services

Industry, government

Spouse retired

Occupational pension

$£ 1-£ 3,000$ wealth

$£ 3,000-£ 10,000$ wealth

$>£ 10,000$ wealth

Missing wealth

Earnings

Spouse earnings

Pension age

Age dummies

$R^{2}$

Option value

Total pension wealth

Spouse pension wealth

Difference in ages

Job tenure

$\%$ of Full-Time employment

Education

Health score

Spouse health score

Renter

Mortgage

Industry, engineering

Industry, manufacturing

Industry, distribution

Industry, services

Spouse retired

(continued)
A. Wealth and Accrual, Men (1,276 observations)

$-8.971 \quad .5268$

\begin{tabular}{|c|c|c|c|c|c|c|}
\hline & & .0326 & .0027 & .0382 & .0064 & -.0211 \\
\hline 27 & .0189 & .0114 & .0021 & .0107 & .0050 & -.0042 \\
\hline .029 & .0026 & .0001 & .0002 & .0036 & .0006 & .0016 \\
\hline
\end{tabular}

$\begin{array}{llllllll}.0072 & .0018 & .0000 & .0002 & .0014 & .0004 & .0000 & .0000\end{array}$

$\begin{array}{llllllll}.0765 & .0464 & .0041 & .0049 & -.0189 & .0117 & .0016 & .0022\end{array}$

$\begin{array}{llllllll}.1296 & .0229 & .0016 & .0024 & .0032 & .0058 & .0021 & .0011\end{array}$

$\begin{array}{llllllll}.0089 & .0126 & -.0001 & .0013 & .0033 & .0031 & -.0008 & .0006\end{array}$

$\begin{array}{llllllll}.0094 & .0075 & -.0006 & .0008 & -.0018 & .0018 & -.0011 & .0003\end{array}$

$\begin{array}{llllllll}-.0205 & .0279 & .0034 & .0029 & -.0012 & .0070 & .0017 & .0013\end{array}$

$\begin{array}{rrrrrrrr}.2254 & .0269 & .0044 & .0029 & .0137 & .0069 & .0045 & .0013\end{array}$

$\begin{array}{llllllll}-.1137 & .0415 & .0066 & .0044 & -.0145 & .0104 & .0046 & .0020\end{array}$

$\begin{array}{llllllll}-.0927 & .0425 & -.0039 & .0045 & -.0400 & .0107 & -.0002 & .0020\end{array}$

$\begin{array}{llllllll}-.0401 & .0413 & .0031 & .0044 & -.0226 & .0103 & .0005 & .0020\end{array}$

$\begin{array}{rrrrrrrr}.0205 & .0404 & .0012 & .0043 & -.0265 & .0101 & .0001 & .0019\end{array}$

$\begin{array}{llllllll}.3681 & .0541 & -.0016 & .0058 & -.0476 & .0138 & -.0030 & .0026\end{array}$

$\begin{array}{llllllll}-.0146 & .0365 & -.0072 & .0039 & -.0061 & .0091 & -.0011 & .0017\end{array}$

$\begin{array}{llllllll}.1923 & .0271 & .0177 & .0028 & .0355 & .0066 & .0149 & .0012\end{array}$

$\begin{array}{llllllll}-.0727 & .0309 & .0060 & .0033 & .0136 & .0077 & .0058 & .0014\end{array}$

$\begin{array}{llllllll}-.0039 & .0350 & .0136 & .0037 & .0297 & .0087 & .0060 & .0016\end{array}$

$\begin{array}{llllllll}.3155 & .0404 & .0236 & .0042 & .0642 & .0099 & .0202 & .0019\end{array}$

$\begin{array}{llllllll}-.0010 & .0557 & .0111 & .0059 & .0133 & .0140 & .0046 & .0027\end{array}$

$\begin{array}{rrrrrrrr}.0272 & .0019 & .0001 & .000 & .0003 & .0004 & .0020 & .0000\end{array}$

$\begin{array}{llllllll}.0025 & .0019 & -.0008 & .0002 & -.0015 & .0004 & -.0003 & .0000\end{array}$

$\begin{array}{llllllll}.4908 & .0623 & -.0166 & .0068 & -.0704 & .0160 & -.0012 & .0031\end{array}$

$\begin{array}{cccc}\text { Yes } & \text { Yes } & \text { Yes } & \text { Yes } \\ .6054 & .5976 & .4890 & .7597\end{array}$

B. Wealth and Accrual, Women (722 observations) $-10.84 \quad .6996$

$\begin{array}{rrrrrrrr}-.1515 & .0211 & .0329 & .0027 & .0183 & .0064 & -.0238 & .0015 \\ .0132 & .0063 & -.0007 & .0018 & -.0022 & .0043 & -.0013 & .0010 \\ -.0033 & .0023 & -.0003 & .0001 & -.0023 & .0012 & -.0005 & .0003 \\ .2429 & .0631 & .0110 & .0054 & .0468 & .0004 & -.0001 & .0001 \\ .1602 & .0396 & .0087 & .0033 & .0324 & .0078 & -.0007 & .0029 \\ -.0228 & .0170 & -.0019 & .0014 & -.0033 & .0033 & -.0014 & .0018 \\ -.0029 & .0164 & .0010 & .0013 & -.0010 & .0032 & .0005 & .0007 \\ .0246 & .0485 & -.0055 & .0041 & -.0160 & .0095 & -.0015 & .0022 \\ .0890 & .0402 & .0026 & .0034 & .0118 & .0079 & .0015 & .0018 \\ -.3168 & .1006 & -.0133 & .0085 & -.0065 & .0199 & .0076 & .0047 \\ -.1573 & .0771 & -.0348 & .0065 & -.0486 & .0152 & -.0065 & .0036 \\ -.2116 & .0747 & -.0259 & .0063 & -.0341 & .0148 & -.0029 & .0035 \\ -.0207 & .0648 & -.0195 & .0054 & -.0107 & .0128 & .0008 & .0030 \\ -.0413 & .0572 & -.0106 & .0048 & -.0188 & .0112 & -.0060 & .0026\end{array}$




\begin{tabular}{|c|c|c|c|c|c|c|c|c|}
\hline \multirow[b]{3}{*}{ Occupational pension } & \multicolumn{8}{|c|}{ Dependent Variable } \\
\hline & \multicolumn{2}{|c|}{$\begin{array}{l}\text { Total Pension } \\
\text { Wealth }\end{array}$} & \multicolumn{2}{|c|}{ Accrual } & \multicolumn{2}{|c|}{ Peak Value } & \multicolumn{2}{|c|}{ Option Value } \\
\hline & .4871 & .0466 & .0159 & .0041 & .0865 & .0095 & .0160 & .0022 \\
\hline$£ 1-£ 10,000$ wealth & .0245 & .0482 & -.0122 & .0040 & -.0250 & .0094 & -.0054 & .0022 \\
\hline$£ 3,000-£ 10,000$ wealth & -.1071 & .0574 & -.0106 & .0048 & -.0200 & .0113 & -.0048 & .0026 \\
\hline$>£ 10,000$ wealth & .2858 & .0644 & -.0101 & .0055 & -.0019 & .0129 & .0006 & .0030 \\
\hline Missing wealth & -.1200 & .0835 & -.0139 & .0070 & -.0243 & .0164 & -.0063 & .0039 \\
\hline Earnings & .0343 & .0045 & .0004 & .0003 & -.0003 & .0007 & .0036 & .0001 \\
\hline Spouse earnings & -.0097 & .0019 & -.0001 & .0001 & -.0010 & .0003 & -.0002 & .0000 \\
\hline Pension age & .0759 & .0827 & -.0183 & .0070 & -.0560 & .0163 & -.0056 & .0038 \\
\hline Age dummies & \multicolumn{2}{|c|}{ Yes } & \multicolumn{2}{|c|}{ Yes } & \multicolumn{2}{|c|}{ Yes } & \multicolumn{2}{|c|}{ Yes } \\
\hline$R^{2}$ & \multicolumn{2}{|c|}{.5683} & \multicolumn{2}{|c|}{.4833} & \multicolumn{2}{|c|}{4546} & \multicolumn{2}{|c|}{.6795} \\
\hline
\end{tabular}

Table 11A.4 Retirement Probabilities: One-Year Accrual, Men (1,276 observations)

\begin{tabular}{|c|c|c|c|c|c|c|c|c|}
\hline & \multicolumn{2}{|c|}{ No Controls } & \multicolumn{2}{|c|}{ Demographics } & \multicolumn{2}{|c|}{$\begin{array}{l}\text { Demographics, } \\
\text { Earnings, and } \\
\text { Cohort Dummies }\end{array}$} & \multicolumn{2}{|c|}{$\begin{array}{l}\text { Demographics, } \\
\text { Earnings, and } \\
\text { Age Dummies }\end{array}$} \\
\hline & $\begin{array}{l}\text { Marginal } \\
\text { Effect }\end{array}$ & SE & $\begin{array}{l}\text { Marginal } \\
\text { Effect }\end{array}$ & SE & $\begin{array}{c}\text { Marginal } \\
\text { Effect }\end{array}$ & SE & $\begin{array}{c}\text { Marginal } \\
\text { Effect }\end{array}$ & SE \\
\hline \multicolumn{9}{|c|}{ A. Not Including Age of First Entitlement to Pension } \\
\hline Pension wealth & .1024 & .0158 & .1152 & .0189 & .1128 & .0185 & .0888 & .0180 \\
\hline Accrual & -1.1481 & .1514 & -1.1869 & .1512 & -.8903 & .1519 & -.1153 & .1768 \\
\hline Spouse wealth & .0176 & .0167 & .0367 & .0167 & .0380 & .0163 & .0302 & .0157 \\
\hline Net earnings & & & & & .0001 & .0013 & .0003 & .0012 \\
\hline Pseudo $R^{2}$ & \multicolumn{2}{|c|}{.0786} & \multicolumn{2}{|c|}{.1435} & \multicolumn{2}{|c|}{.1869} & \multicolumn{2}{|c|}{.2337} \\
\hline Log-likelihood & \multicolumn{2}{|c|}{-463.2} & \multicolumn{2}{|c|}{-430.5} & \multicolumn{2}{|c|}{-408.7} & \multicolumn{2}{|c|}{385.2} \\
\hline$F$ test (PW, Accrual) & \multicolumn{2}{|c|}{76.71} & \multicolumn{2}{|c|}{83.25} & \multicolumn{2}{|c|}{61.87} & \multicolumn{2}{|c|}{24.29} \\
\hline \multicolumn{9}{|c|}{ B. Including Age of First Entitlement to Pension (Penage) } \\
\hline Pension wealth & .0638 & .0166 & .0812 & .0193 & .0853 & .0192 & .0802 & .0185 \\
\hline Accrual & -.6461 & .1632 & -.7627 & .1604 & -.6342 & .1588 & -.1049 & .1777 \\
\hline Spouse wealth & .0062 & .0166 & .0254 & .0167 & .0283 & .0165 & .0276 & .0156 \\
\hline Penage dummy & .2649 & .0498 & .2205 & .0484 & .1594 & .0455 & .0955 & .0634 \\
\hline Net earnings & & & & & .0004 & .0013 & .0004 & .0012 \\
\hline Pseudo $R^{2}$ & \multicolumn{2}{|c|}{.1229} & \multicolumn{2}{|c|}{.1831} & \multicolumn{2}{|c|}{.2074} & \multicolumn{2}{|c|}{.2370} \\
\hline Log-likelihood & \multicolumn{2}{|c|}{-440.9} & \multicolumn{2}{|c|}{-410.1} & \multicolumn{2}{|c|}{-390.4} & \multicolumn{2}{|c|}{-383.5} \\
\hline$F$ test (PW, Accrual) & \multicolumn{2}{|c|}{21.33} & \multicolumn{2}{|c|}{29.50} & \multicolumn{2}{|c|}{27.76} & \multicolumn{2}{|c|}{18.71} \\
\hline
\end{tabular}

Note: $\mathrm{SE}=$ standard error. 


\begin{tabular}{|c|c|c|c|c|c|c|c|c|}
\hline & \multicolumn{2}{|c|}{ No Controls } & \multicolumn{2}{|c|}{ Demographics } & \multicolumn{2}{|c|}{$\begin{array}{c}\text { Demographics, } \\
\text { Earnings, and } \\
\text { Cohort Dummies }\end{array}$} & \multicolumn{2}{|c|}{$\begin{array}{l}\text { Demographics, } \\
\text { Earnings, and } \\
\text { Age Dummies }\end{array}$} \\
\hline & $\begin{array}{c}\text { Marginal } \\
\text { Effect }\end{array}$ & SE & $\begin{array}{c}\text { Marginal } \\
\text { Effect }\end{array}$ & SE & $\begin{array}{c}\text { Marginal } \\
\text { Effect }\end{array}$ & SE & $\begin{array}{c}\text { Marginal } \\
\text { Effect }\end{array}$ & SE \\
\hline \multicolumn{9}{|c|}{ A. Not Including Age of First Entitlement to Pension } \\
\hline Pension wealth & .0851 & .0150 & .0923 & .0181 & .0982 & .0179 & .0868 & .0175 \\
\hline Peak value & -.5018 & .0766 & -.5054 & .0759 & -.3211 & .0779 & -.0283 & .0764 \\
\hline Spouse wealth & .0114 & .0167 & .0246 & .0168 & .0296 & .0165 & .0290 & .0155 \\
\hline Net earnings & & & & & .0004 & .0013 & .0002 & .0012 \\
\hline Pseudo $R^{2}$ & \multicolumn{2}{|c|}{.0625} & \multicolumn{2}{|c|}{.1225} & \multicolumn{2}{|c|}{1662} & \multicolumn{2}{|c|}{.2334} \\
\hline Log-likelihood & \multicolumn{2}{|c|}{-471.3} & \multicolumn{2}{|c|}{-441.1} & \multicolumn{2}{|c|}{-419.1} & \multicolumn{2}{|c|}{-385.4} \\
\hline$F$ test (PW, Accrual) & \multicolumn{2}{|c|}{59.96} & 62 & & \multicolumn{2}{|c|}{42.61} & \multicolumn{2}{|c|}{24.08} \\
\hline & \multicolumn{6}{|c|}{ B. Including Age of First Entitlement to Pension (Penage) } & \multirow[b]{2}{*}{.0780} & \multirow[b]{2}{*}{.0181} \\
\hline Pension wealth & .0514 & .0155 & .0628 & .0183 & .0702 & .0185 & & \\
\hline Peak value & -.2689 & .0793 & -.3041 & .0777 & -.2045 & .0787 & -.0141 & .0763 \\
\hline Spouse wealth & .0022 & .0165 & .0167 & .0166 & .0206 & .0165 & .0264 & .0155 \\
\hline Penage dummy & .2935 & .0489 & .2602 & .0485 & .2007 & .0470 & .0953 & .0635 \\
\hline Net earnings & & & & & .0006 & .0013 & .0004 & .0012 \\
\hline Pseudo $R^{2}$ & .11 & & .17 & & .19 & & .23 & \\
\hline Log-likelihood & -44 & & -41 & & -40 & & -38 & \\
\hline$F$ test (PW, Accrual) & 16. & & 22 & & 18 & & 18 & \\
\hline
\end{tabular}

Note: $\mathrm{SE}=$ standard error.

Table 11A.6 Retirement Probabilities: One-Year Accruals, Women (722 observations)

\begin{tabular}{|c|c|c|c|c|c|c|c|c|}
\hline & \multicolumn{2}{|c|}{ No Controls } & \multicolumn{2}{|c|}{ Demographics } & \multicolumn{2}{|c|}{$\begin{array}{c}\text { Demographics, } \\
\text { Earnings, and } \\
\text { Cohort Dummies }\end{array}$} & \multicolumn{2}{|c|}{$\begin{array}{l}\text { Demographics, } \\
\text { Earnings, and } \\
\text { Age Dummies }\end{array}$} \\
\hline & $\begin{array}{c}\text { Marginal } \\
\text { Effect }\end{array}$ & SE & $\begin{array}{c}\text { Marginal } \\
\text { Effect }\end{array}$ & $\mathrm{SE}$ & $\begin{array}{c}\text { Marginal } \\
\text { Effect }\end{array}$ & SE & $\begin{array}{c}\text { Marginal } \\
\text { Effect }\end{array}$ & $\mathrm{SE}$ \\
\hline \multicolumn{9}{|c|}{ A. Not Including Age of First Entitlement to Pension } \\
\hline Pension wealth & .0862 & .0256 & .0827 & .0279 & .0821 & .0276 & .0710 & .0262 \\
\hline Accrual & -.6064 & .3176 & -.6549 & .3398 & -.5645 & .3296 & -.0521 & .3181 \\
\hline Spouse wealth & .0247 & .0158 & .0226 & .0170 & .0314 & .0174 & .0309 & .0166 \\
\hline Net earnings & & & & & -.0007 & .0030 & -.0025 & .0028 \\
\hline Pseudo $R^{2}$ & \multicolumn{2}{|c|}{.0188} & \multicolumn{2}{|c|}{.0702} & \multicolumn{2}{|c|}{.0973} & \multicolumn{2}{|c|}{.1306} \\
\hline Log-likelihood & \multicolumn{2}{|c|}{-313.9} & \multicolumn{2}{|c|}{-297.4} & \multicolumn{2}{|c|}{-288.8} & \multicolumn{2}{|c|}{-278.1} \\
\hline$F$ test (PW, Accrual) & \multicolumn{2}{|c|}{11.29} & \multicolumn{2}{|c|}{9.38} & \multicolumn{2}{|c|}{9.29} & \multicolumn{2}{|c|}{8.23} \\
\hline & \multicolumn{6}{|c|}{ B. Including Age of First Entitlement to Pension (Penage) } & \multirow[b]{2}{*}{.0678} & \multirow[b]{2}{*}{.0264} \\
\hline Pension wealth & .0730 & .0256 & .0694 & .0278 & .0694 & .0275 & & \\
\hline Accrual & -.3590 & .3206 & -.4076 & .3409 & -.3523 & .3307 & -.0170 & .3202 \\
\hline Spouse wealth & .0223 & .0157 & .0199 & .0169 & .0290 & .0172 & .0298 & .0166 \\
\hline Penage dummy & .1312 & .0414 & .1228 & .0411 & .1063 & .0399 & .0543 & .0655 \\
\hline Net earnings & & & & & -.0009 & .0030 & -.0025 & .0028 \\
\hline Pseudo $R^{2}$ & \multicolumn{2}{|c|}{.0378} & \multicolumn{2}{|c|}{.0874} & \multicolumn{2}{|c|}{.1109} & \multicolumn{2}{|c|}{.1319} \\
\hline Log-likelihood & \multicolumn{2}{|c|}{-307.8} & \multicolumn{2}{|c|}{-291.9} & \multicolumn{2}{|c|}{-274.4} & \multicolumn{2}{|c|}{-277.7} \\
\hline$F$ test (PW, Accrual) & \multicolumn{2}{|c|}{8.58} & \multicolumn{2}{|c|}{6.27} & \multicolumn{2}{|c|}{6.36} & \multicolumn{2}{|c|}{7.69} \\
\hline
\end{tabular}

Note: $\mathrm{SE}=$ standard error. 
Table 11A.7 Retirement Probabilities: Peak Values, Women (722 observations)

\begin{tabular}{|c|c|c|c|c|c|c|c|c|}
\hline & \multicolumn{2}{|c|}{ No Controls } & \multicolumn{2}{|c|}{ Demographics } & \multicolumn{2}{|c|}{$\begin{array}{c}\text { Demographics, } \\
\text { Earnings, and } \\
\text { Cohort Dummies }\end{array}$} & \multicolumn{2}{|c|}{$\begin{array}{l}\text { Demographics, } \\
\text { Earnings, and } \\
\text { Age Dummies }\end{array}$} \\
\hline & $\begin{array}{c}\text { Marginal } \\
\text { Effect }\end{array}$ & SE & $\begin{array}{c}\text { Marginal } \\
\text { Effect }\end{array}$ & SE & $\begin{array}{c}\text { Marginal } \\
\text { Effect }\end{array}$ & SE & $\begin{array}{c}\text { Marginal } \\
\text { Effect }\end{array}$ & $\mathrm{SE}$ \\
\hline \multicolumn{9}{|c|}{ A. Not Including Age of First Entitlement to Pension } \\
\hline Pension wealth & .0735 & .0225 & .0657 & .0251 & .0673 & .0253 & .0712 & .0244 \\
\hline Peak value & -.2388 & .1407 & -.3990 & .1781 & -.3608 & .1707 & -.1791 & .1592 \\
\hline Spouse wealth & .0231 & .0158 & .0185 & .0170 & .0278 & .0173 & .0296 & .0166 \\
\hline Net earnings & & & & & -.0011 & .0031 & -.0027 & .0028 \\
\hline Pseudo $R^{2}$ & \multicolumn{2}{|c|}{.0711} & \multicolumn{2}{|c|}{.0730} & \multicolumn{2}{|c|}{.1004} & \multicolumn{2}{|c|}{.1327} \\
\hline Log-likelihood & \multicolumn{2}{|c|}{-314.2} & \multicolumn{2}{|c|}{-296.5} & \multicolumn{2}{|c|}{-287.8} & \multicolumn{2}{|c|}{-277.4} \\
\hline$F$ test (PW, Accrual) & \multicolumn{2}{|c|}{10.94} & \multicolumn{2}{|c|}{11.04} & \multicolumn{2}{|c|}{11.04} & \multicolumn{2}{|c|}{9.37} \\
\hline & \multicolumn{6}{|c|}{ B. Including Age of First Entitlement to Pension (Penage) } & \multirow[b]{2}{*}{.0693} & \multirow[b]{2}{*}{.0245} \\
\hline Pension wealth & .0668 & .0224 & .0597 & .0250 & .0607 & .0252 & & \\
\hline Peak value & -.1634 & .1392 & -.3151 & .1752 & -.2930 & .1684 & -.1627 & .1607 \\
\hline Spouse wealth & .0216 & .0156 & .0169 & .0168 & .0264 & .0172 & .0289 & .0166 \\
\hline Penage dummy & .1340 & .0409 & .1223 & .0404 & .1055 & .0392 & .0454 & .0646 \\
\hline Net earnings & & & & & -.0012 & .0030 & -.0027 & .0028 \\
\hline Pseudo $R^{2}$ & .03 & & .0 & & .1 & & .13 & \\
\hline Log-likelihood & -30 & & -29 & & -28 & & -27 & \\
\hline$F$ test (PW, Accrual) & 8. & & 8. & & 8. & & 8. & \\
\hline
\end{tabular}

Note: $\mathrm{SE}=$ standard error. 


\begin{tabular}{|c|c|c|c|c|c|c|c|c|}
\hline & \multicolumn{4}{|c|}{ Men } & \multicolumn{4}{|c|}{ Women } \\
\hline & \multicolumn{2}{|c|}{$\begin{array}{l}\text { Demographics, } \\
\text { earnings, and } \\
\text { cohort dummies }\end{array}$} & \multicolumn{2}{|c|}{$\begin{array}{l}\text { Demographics, } \\
\text { earnings, and } \\
\text { age dummies }\end{array}$} & \multicolumn{2}{|c|}{$\begin{array}{c}\text { Demographics, } \\
\text { earnings, and } \\
\text { cohort dummies }\end{array}$} & \multicolumn{2}{|c|}{$\begin{array}{c}\text { Demographics, } \\
\text { earnings, and } \\
\text { age dummies }\end{array}$} \\
\hline & $\begin{array}{l}\text { Marginal } \\
\text { Effect }\end{array}$ & SE & $\begin{array}{c}\text { Marginal } \\
\text { Effect }\end{array}$ & SE & $\begin{array}{c}\text { Marginal } \\
\text { Effect }\end{array}$ & SE & $\begin{array}{c}\text { Marginal } \\
\text { Effect }\end{array}$ & SE \\
\hline Total wealth & .0282 & .0195 & .0650 & .0198 & .0302 & .0282 & .0594 & .0280 \\
\hline Option value & -1.559 & .3650 & -.6130 & .4431 & -1.243 & .6109 & -.3382 & .6152 \\
\hline Spouse wealth & .0123 & .0162 & .0243 & .0154 & .0251 & .0172 & .0291 & .0166 \\
\hline Net earnings & .0032 & .0014 & .0014 & .0014 & .0032 & .0036 & -.0014 & .0034 \\
\hline Spouse net earnings & -.0031 & .0016 & -.0027 & .0015 & -.0017 & .0016 & -.0021 & .0015 \\
\hline Pension age & .2135 & .0464 & .0985 & .0636 & .1126 & .0392 & .0523 & .0650 \\
\hline Difference in ages & -.0010 & .0021 & -.0033 & .0021 & -.0067 & .0049 & -.0065 & .0048 \\
\hline Job tenure & .0005 & .0013 & -.0001 & .0012 & .0028 & .0018 & .0029 & .0018 \\
\hline $\begin{array}{c}\% \text { of Full-Time } \\
\text { employment }\end{array}$ & .0213 & .0356 & .0419 & .0338 & .0361 & .0505 & .0307 & .0487 \\
\hline Education & -.0147 & .0191 & -.0195 & .0187 & -.0143 & .0330 & .0035 & .0319 \\
\hline Health score & .0158 & .0086 & .0205 & .0083 & .0229 & .0131 & .0265 & .0127 \\
\hline Spouse health score & -.0078 & .0062 & -.0086 & .0059 & -.0210 & .0155 & -.0236 & .0147 \\
\hline Renter & -.0021 & .0224 & -.0155 & .0202 & -.0154 & .0369 & -.0035 & .0374 \\
\hline Mortgage & -.0254 & .0216 & -.0388 & .0197 & -.0346 & .0320 & -.0313 & .0307 \\
\hline Industry, engineering & .0280 & .0354 & .0511 & .0384 & .0119 & .0847 & -.0107 & .0730 \\
\hline Industry, & & & & & & & & \\
\hline manufacturing & -.0218 & .0306 & .0022 & .0335 & -.0397 & .0522 & -.0441 & .0492 \\
\hline Industry, distribution & -.0187 & .0286 & -.0038 & .0306 & .0525 & .0689 & .0535 & .0674 \\
\hline Industry, services & -.0547 & .0240 & -.0469 & .0241 & -.0179 & .0527 & -.0283 & .0515 \\
\hline Industry, government & -.0285 & .0327 & -.0197 & .0340 & & & & \\
\hline Spouse retired & .0769 & .0378 & .0604 & .0352 & .1496 & .0603 & .1325 & .0585 \\
\hline $\begin{array}{l}\text { Occupational } \\
\text { pension }\end{array}$ & .0535 & .0184 & .0490 & .0182 & .0428 & .0428 & .0381 & .0412 \\
\hline$£ 1-£ 3,000$ wealth & .0237 & .0270 & .0260 & .0260 & -.0030 & .0405 & -.0052 & .0395 \\
\hline$£ 3,000-£ 10,000$ & & & & & & & & \\
\hline wealth & .0473 & .0351 & .0398 & .0335 & .0295 & .0509 & .0434 & .0523 \\
\hline$>£ 10,000$ wealth & .0607 & .0423 & .0255 & .0363 & -.0097 & .0522 & -.0321 & .0457 \\
\hline Missing wealth & .0330 & .0552 & .0405 & .0565 & -.0287 & .0658 & -.0534 & .0518 \\
\hline Cohort born 1934 & -.0168 & .0368 & & & & & & \\
\hline Cohort born 1935 & -.0350 & .0327 & & & & & & \\
\hline Cohort born 1936 & .0094 & .0474 & & & & & & \\
\hline Cohort born 1937 & -.0364 & .0320 & & & & & & \\
\hline Cohort born 1938 & -.0406 & .0302 & & & .0834 & .0590 & & \\
\hline Cohort born 1939 & -.0632 & .0265 & & & .0260 & .0440 & & \\
\hline Cohort born 1940 & -.0668 & .0265 & & & .0440 & .0425 & & \\
\hline Cohort born 1941 & -.0729 & .0249 & & & .0843 & .0355 & & \\
\hline Cohort born 1942 & -.0411 & .0367 & & & .1098 & .0346 & & \\
\hline
\end{tabular}




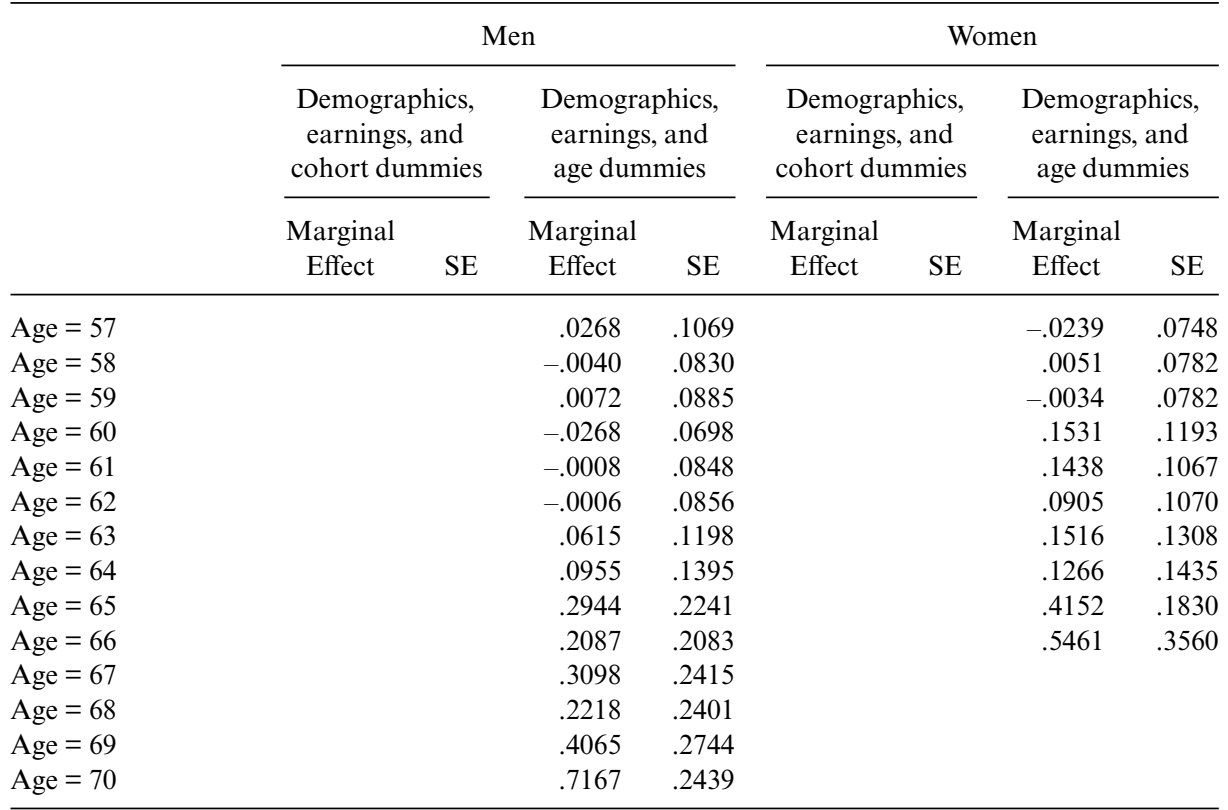

Note: $\mathrm{SE}=$ standard error.

Table 11A.9

\begin{tabular}{lccc}
\hline & $\begin{array}{c}\text { Linear Age } \\
\text { (Marginal Effect) }\end{array}$ & $\begin{array}{c}\text { Cohort Dummies } \\
\text { (Marginal Effect) }\end{array}$ & $\begin{array}{c}\text { Age Dummies } \\
\text { (Marginal Effect) }\end{array}$ \\
\hline Sample size & $\begin{array}{c}\text { A. Excluding } \\
\text { Age First Eligible }\end{array}$ & \\
Pension wealth & $1,202-1,375$ & $1,183-1,347$ & $1,158-1,345$ \\
$\quad$ Mean estimate & .0749 & .0464 & .0692 \\
$5 \%$ & .0383 & .0089 & .0372 \\
$95 \%$ & .1083 & .0808 & .1014 \\
Option value & & & -.6032 \\
Mean estimate & -.3861 & -1.9043 & -1.3079 \\
$5 \%$ & -1.2363 & -2.6422 & .0747 \\
$95 \%$ & .4071 & -1.2743 & $1,106-1,350$ \\
& $B$. Including & Age First Eligible & \\
Sample size & $1,194-1,345$ & $1,179-1,359$ & .0629 \\
Pension wealth & & & .0283 \\
Mean estimate & .0510 & .0192 & .1068 \\
$5 \%$ & .0156 & -.0235 & \\
$95 \%$ & .0815 & .0555 & -.6833 \\
Option value & & & -1.4395 \\
Mean estimate & -.3706 & -1.7371 & -.0250 \\
$5 \%$ & -1.1093 & -2.4786 & \\
$95 \%$ & .2624 & -1.1214 & \\
\hline
\end{tabular}




\section{References}

Banks, J., and C. Emmerson. 2000. Public and private pension spending: principles, practice and the need for reform. Fiscal Studies 21 (1): 1-63.

Blundell, R., and P. Johnson. 1998. Pensions and labor force participation in the UK. American Economic Review 88 (2): 173-78.

1999. Pensions and retirement in the UK. In Social security and retirement around the world, ed. J. Gruber and D. Wise, 403-36. Chicago: University of Chicago Press.

Bone, M., J. Gregory, B. Gill, and D. Lader. 1992. Retirement and retirement plans. London: Her Majesty's Stationary Office (HMSO) for Office of Population Census and Surveys.

Department of Social Security and Office for Population and Census Surveys. Various years. Retirement Survey. London: Department of Social Security.

Disney, R. 1996. Can We Afford to Grow Older? A Perspective on the Economics of Aging. Cambridge, Mass.: MIT Press.

Disney, R., C. Meghir, and E. Whitehouse. 1994. Retirement behaviour in Britain. Fiscal Studies 15 (1): 24-43.

Disney, R., and S. Smith. 2002. The labour supply effects of the abolition of the earnings rule. Economic Journal 112 (478): C136-C152.

Disney, R., and G. Stears. 1996. Why is there a decline in defined benefit plan membership? Working Paper no. 96/4. London: Institute for Fiscal Studies.

Johnson, P. 1999. Older Getting Wiser. Sydney: Institute of Chartered Accountants in Australia.

National Association of Pension Funds (NAPF). 1998. Annual survey of occupational pension schemes 1997. London: NAPF.

Stock, J., and D. Wise. 1990. Pensions, the option value of work and retirement. Econometrica 58 (5): 1151-80.

U.K. Data Archive. 1996. Family expenditures survey 1994-1995. http://www.dataarchive.ac.uk/finding Data/snDescription.asp?sn $=3478$. 
